\title{
18. ISOTOPIC SURVEY OF DIAGENETIC CARBONATES, DEEP SEA DRILLING PROJECT LEG 631
}

\author{
Kenneth A. Pisciotto, Deep Sea Drilling Project, Scripps Institution of Oceanography, La Jolla, California \\ and \\ John J. Mahoney, Geologic Research Division, Scripps Institution of Oceanography, La Jolla, California
}

\begin{abstract}
Authigenic carbonates, principally calcium-rich dolomites, with extremely variable isotopic compositions were recovered in organic-rich marine sediments during Leg 63 drilling off southern California and Baja California. These carbonates occur as thin layers in fine-grained, diatomaceous sediments and siliceous rocks, mostly deposited during the Neogene. A combination of textural, geochemical, and isotopic evidence indicates these dolomites formed as cements and precipitates in shallow subsurface zones of high alkalinity spawned by abundant $\mathrm{CO}_{2}$ and methane production during progressive microbial decay of organic matter. Depths and approximate temperatures of formation estimated from oxygen isotopes are 87 to 658 meters and $10^{\circ} \mathrm{C}$ to $50^{\circ} \mathrm{C}$, respectively. Within any sedimentary section, dolomites may form simultaneously at several depths or at different times within the same interval. Highly variable carbon isotopes $(-30$ to $+16 \%$ ) reflect the isotopic reservoir in which the carbonates formed. Oxidation of organic matter through microbial reduction of sulfate at shallow depths favors light-carbon carbonates such as those at Sites 468 and 471; heavy-carbon carbonates at Site 467 most likely formed below this zone where $\mathrm{HC}^{12} \mathrm{O}_{3}{ }^{-}$is preferentially removed by reduction of $\mathrm{CO}_{2}$ to methane during methanogenesis. An important controlling factor is the sedimentation rate, which dictates both the preservation of organic matter on the sea floor and depth distribution of subsurface zones of organic-matter decay.
\end{abstract}

\section{INTRODUCTION}

The publicity surrounding the discovery of primary dolomite forming in hypersaline settings (e.g., Deffeyes et al., 1964; Kinsman, 1965; Shinn et al., 1965) and the recognition of the quantitative importance of secondary dolomitization of existing limestones and carbonate sediments through reflux of mixed meteoric and hypersaline waters (e.g., Badiozamani, 1973; Dunham and Olson, 1979) tend to overshadow a third significant site of dolomite formation-the deep-sea environment. Reports of scattered rhombic crystals and detrital grains in deep-sea sediments are common (summary and references in Milliman, 1974). Yet more intriguing are dolomitic cements, layers, and concretionary zones associated with rapidly deposited, organic-rich, finegrained sediments along continental margins and in small ocean basins (e.g., Russell et al., 1967; Murata et al., 1969; Deuser, 1970; Supko et al., 1974; Hein et al., 1979; McKenzie et al., 1980). This lithologic affiliation-dolomite and organic-rich sediments-and the extreme variability of carbon and oxygen isotopic compositions observed in these carbonates directed a number of investigators to postulate formative conditions of shallow burial and low temperature in association with carbon dioxide and methane produced during the microbial breakdown of organic matter (e.g., Spotts and Silverman, 1966; Hathaway and Degens, 1969; Deuser, 1970; Murata et al., 1969; Irwin et al., 1977; Hein et al., 1979; Friedman and Murata, 1979).

\footnotetext{
${ }^{1}$ Initial Reports of the Deep Sea Drilling Project, Volume 63.
}

During Leg 63 we recovered authigenic carbonates at six sites off southern California and Baja California (Fig. 1). This report interprets the origin of these carbonates at selected sites on the basis of sedimentological, textural, chemical, and isotopic data presented herein.

\section{METHODS}

We surveyed macroscopic textures of the authigenic carbonates of this study from slabbed core surfaces. Detailed information on microtextures of selected specimens comes from smear slides, thin sections, and scanning electron microscopy (SEM). We used x-ray diffraction (XRD) scanning at $2 \theta=1 \% \mathrm{~min}$ employing nickel-filtered $\mathrm{CuK} \alpha$ radiation to establish carbonate mineralogy and overall compositions of the associated sediments. Detailed XRD scans at $2 \theta=$ $1 / 2 \%$ min provided estimates of the $\mathrm{MgCO}_{3}$ content (mole \%) of dolomites and calcites (Goldsmith and Graf, 1958). We made no chemical determinations of iron or manganese in these carbonates. Solution chemistry of interstitial waters and total organic carbon analyses of associated sediments were measured aboard the Glomar Challenger during Leg 63. Additional measurements of total organic carbon of the authigenic carbonates of this study were preformed onshore using a LECO WR-12 carbon analyzer.

Carbon- 13 and oxygen-18 analyses were done commercially through Geochron Laboratories in Cambridge, Massachusetts. The method of $\mathrm{CO}_{2}$ extraction with phosphoric acid follows McCrea (1950), using standard corrections discussed by Craig (1957). We report all values in parts per thousand $(\%)$ using the standard delta notation:

$$
\delta \mathrm{C}^{13} \text { or } \delta \mathrm{O}^{18}=\left[\left(\mathrm{R}_{\text {sample }} / \mathrm{R}_{\text {standard }}\right)-1\right] \times 10^{3}
$$

where $\mathrm{R}$ is ${ }^{13} \mathrm{C} /{ }^{12} \mathrm{C}$ or ${ }^{18} \mathrm{O} /{ }^{16} \mathrm{O}$. The standard for carbon is $\mathrm{PDB}$, that for oxygen, Standard Mean Ocean Water (SMOW). The conversion of $\delta \mathrm{O}^{18}$ SMOw values to $\delta \mathrm{O}^{18}$ PDB follows Friedman and O'Neil (1977). We subtracted $0.8 \%$ from all dolomite $\delta \mathrm{O}^{18}$ values to account for the acid fractionation relative to calcite (Sharma and Clayton, 1965). Reproducibility was variable, $\pm 0.7 \%$ for $\delta \mathrm{C}^{13}$ and $\pm 0.2 \%$ for $\delta \mathrm{O}^{18}$, probably because small amounts of organic matter reacted with the 


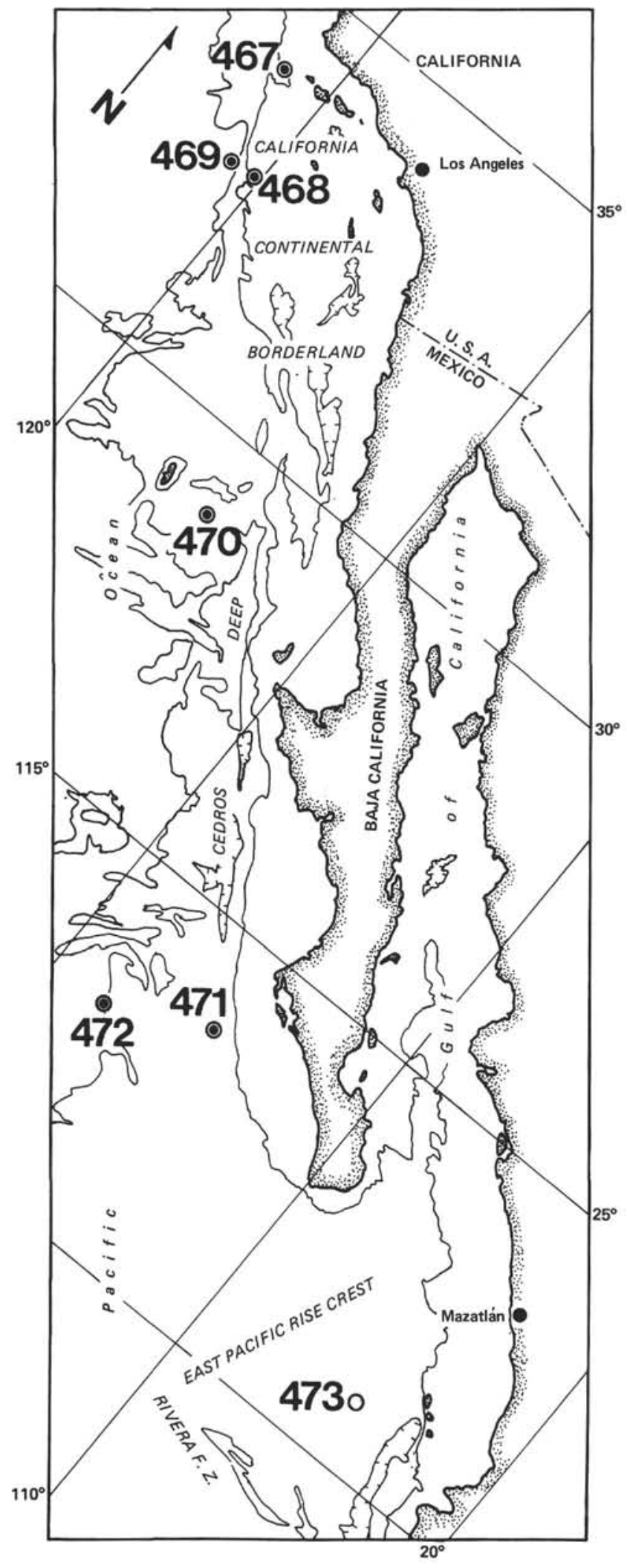

Figure 1. Location map of Leg 63 sites. (Filled symbols are sites with authigenic carbonate.) phosphoric acid. For samples containing both calcite and dolomite, we dissolved calcite prior to isotopic analyses by repeated washings with small amounts of $0.1 M$ acetic acid buffered at $p \mathrm{H}=5$, verifying complete calcite removal with XRD (M. Kastner, personal communication, 1979). This treatment may also remove minor amounts of dolomite, particularly the finer-grained crystals.

\section{DISTRIBUTION OF CARBONATES AND ASSOCIATED LITHOFACIES}

Figures 1 and 2 summarize the distribution of diagenetic carbonates and associated lithofacies at Leg 63 sites. At Site 467 in the outer California Continental Borderland and at Site 471 off Magdalena Bay, Baja California, these dolomites and dolomitic limestones occur as discrete, decimeter-thick zones in pyrite-bearing, diatomaceous sediments, porcellanites, and siliceous rocks; these zones are reminiscent of concretionary carbonates that punctuate similar Neogene siliceous strata in the circum-Pacific region (Fig. 3). The thickest interval we recovered measures 1.3 meters (Section 467-63-1), although the range is typically less -10 to 50 $\mathrm{cm}$. Spacing between intervals varies in the range of 9 to 67 meters at Site 467 and 8 to 132 meters at Site 471 . Degree of cementation is also variable; centers of single carbonate intervals are commonly hard and wellcemented, with decreasing carbonate content above and below. Sedimentary structures within the carbonate intervals include abundant burrows and lenticular bedding (Fig. 3, A). These structures are identical to those in the enclosing host sediment, but are often better preserved due to superior recovery of the limey intervals (e.g., Fig. 3, A and D).

Diagenetic carbonates recovered at Site 468 are dolomitic silty claystones that are interbedded with volcaniclastic sediments-andesitic breccia, lapilli tuff, and volcaniclastic sandstone (Fig. 2). These sediments occur below about 250 meters in Hole $468 \mathrm{~B}$ at this site. A single fragment was recovered at 184 meters in Hole 468.

At Site 469 in the outer California Continental Borderland and at Sites 470 and $\mathbf{4 7 2}$ off Baja California, dolomite occurs in clayey and chalky sediments immediately above contacts with igneous rocks (Fig. 2). At Site 469 , the dolomitic interval is a burrow-mottled, quartz-cemented chalk about $5 \mathrm{~cm}$ thick. Dolomite at Sites 470 and 472 occurs as scattered rhombic crystals associated with pyrite and manganese mineralization in clayey nannofossil chalk and nannofossil clay. An approximately meter-thick section of chalk immediately overlying basalt is dolomitic at Site 470 , just as at the nearby experimental Mohole site (Murata and Erd, 1964). At Site 472 , several thin $(5-10 \mathrm{~cm})$ intervals of iron-rich, dolomitic nannofossil ooze occur in Core 12 about 10 meters above basalt.

\section{MINERALOGY AND TEXTURE}

Calcium-rich dolomite is the principal diagenetic carbonate in the samples investigated in this study. Magne- 
sium contents are variable (44-51 mole $\% \mathrm{MgCO}_{3}$; Table 1), and weak XRD ordering reflections are present. Calcite occurring with dolomite in many of the samples from Site 467 is principally low-magnesium calcite comprising primary coccolith debris. The single diagenetic limestone encountered is also composed of low-magnesium calcite (Sample 471-33,CC, Table 1).

Leg 63 authigenic carbonates display a complete spectrum of microtextures-from dolomitic silty claystones (with a scattered distribution of small dolomite crystals set in a clayey matrix containing detrital quartz and feldspar and well-preserved foraminifers) to clayey dolomites composed of interlocking, 5 to $10 \mu \mathrm{m}$-size crystals (Fig. 4 A-C). Dolomite cements or impregnates the host claystone or siliceous ooze rather than replaces existing biogenic carbonate. Foraminifers are typically well preserved with only sparse intrachamber growths of dolomite, analcime, and clinoptilolite crystals (Fig. 4 D-F). Likewise, coccoliths are commonly unaltered and often occur adjacent to euhedral dolomite crystals (Fig. 4, G-H). The poorly indurated limestone (Sample $471-37, C C)$ has a sugary texture both in hand specimen and thin section. In this sample, individual calcite grains appear fragmental with ragged edges, perhaps an indication of some transport prior to deposition (Fig. 4, I).

\section{CARBON AND OXYGEN ISOTOPES}

We measured carbon and oxygen isotopes of authigenic carbonates only at Sites 467,468 , and 471 . Table 1 lists these results and Figure 5 displays them along with other subsurface data. At Site 467 both $\delta \mathrm{C}^{13}$ and $\delta \mathrm{O}^{18}$ values of dolomites generally decrease with depth. Carbon values have the largest range, $+15.8 \%$ at a depth of 148 meters to $-4.7 \%$ at 881 meters. Oxygen values vary from $35.5 \%$ to $31.4 \%$ (SMOW) over the same interval. Two nannofossil claystones (calcite) analyzed yield $\delta \mathrm{C}^{13}$ and $\delta \mathrm{O}^{18}$ values similar to those of the closest dolomites, but within the range of biogenic calcite (e.g., Milliman, 1974).

Four isotopic analyses of dolomitic silty claystones at Site 468 also show an apparent decrease in both $\delta C^{13}$ and $\delta \mathrm{O}^{18}$ with depth. Oxygen values are in the range of those at Site 467; carbon isotopes match those of some of the deeper dolomites at Site 467.

At Site $471, \delta \mathrm{O}^{18}$ values remain nearly constant with depth. In contrast, carbon isotopes increase markedly from very negative values at about 180 to 190 meters $(-23.2$ to $-29.8 \%$ ) to heavier carbon at 366 meters $(+0.8 \%)$. A dolomite well below this depth at 602 meters has $\delta \mathrm{C}^{13}=3.3 \%$. The diagenetic limestone is unique in having both light carbon $(-9.6 \%$ ) and oxygen $\left(20.7 \%\right.$ ) values. Although actual $\delta C^{13}$ values differ, a minor excursion toward lighter $\delta \mathrm{C}^{13}$ compositions at about $9 \mathrm{Ma}$ (180-200 meters) at Site 471 matches a similar variation at a corresponding age (620-640 meters) at Site 467 . Otherwise there is little overlap in time for any of the samples analyzed at the three sites.

\section{TOTAL ORGANIC CARBON}

Table 1 lists total organic carbon values for analyzed carbonates at Sites 467, 468, and 471; Figure 5 plots these data along with additional organic carbon analyses of associated sediments. Values are highest and most variable at Site 467 , especially between 350 to 720 meters $(\sim 4.5-10.5 \mathrm{Ma})$. The dolomites and dolomitic limestones almost always have organic carbon contents lower than those of the enclosing sediments.

At Sites 468 and 471 , dolomites and associated sediments generally contain between $0.5 \%$ to $1.0 \%$ organic carbon, still high but less than the amounts at Site 467 . We note a general association of high organic carbon contents with heavy-carbon carbonates $(\geq+1.0 \%$ ) at Site 467 and lower organic carbon values with lightcarbon carbonates $(\leq+1.0 \%)$ at Sites 468 and 471 , although sample by sample correlations are extremely variable.

\section{INTERSTITIAL WATER CHEMISTRY}

Shipboard geochemical analyses of interstitial water squeezed from sediments recovered at Sites 467, 468, and 471 are displayed on Figure 5. Calcium and magnesium profiles at Sites 467 and 471 typify results at many DSDP sites (e.g., Gieskes, 1975; Sayles and Manheim, 1975). At Site 468 calcium increases and magnesium decreases only slightly with depth. Alkalinity profiles at Sites 468 and 471 indicate low values of bicarbonate and perhaps a slight decrease with depth. In contrast, a pronounced alkalinity maximum at Site 467 coincides with the depth of the shallowest dolomite ( $\sim 150$ meters). Sulfate drops rapidly to zero at a sub-bottom depth of about 63 meters at Site 467 . At Site 471, sulfate depletion occurs between 123 and 412 meters. No apparent depletion occurs at Site 468.

Salinity remains constant at near normal ocean-water values at Site 468 but decreases several parts per mil with depth at Sites 467 and 471 . And $p \mathrm{H}$ is nearly invariant $(\simeq 7)$ at Site 467 ; it increases slightly with depth at Site 468 . The $p \mathrm{H}$ profile at Site 471 is more variable, decreasing from 8 to 7 over the first hundred meters, then increasing to 7.5 at greater depths.

\section{DISCUSSION}

\section{Geochemical Considerations}

$\mathrm{Mg} / \mathrm{Ca}$ ratios, salinity, temperature, and reaction kinetics are major factors influencing the formation of dolomite, either by direct precipitation from solution or by transformation of existing carbonates (Folk and Land, 1975). In evaporitic settings and hypersaline environments, primary precipitation of dolomite is apparently favored by: (1) high $\mathrm{Mg} / \mathrm{Ca}$ molar ratios $(\sim 6-10)$, facilitated by the precipitation of gypsum and the concomitant loss of $\mathrm{Ca}$; (2) high activity of $\mathrm{Mg}$ relative to $\mathrm{Ca}$ in the brine, presumably to ensure a high degree of ordering in the dolomite lattice and to overcome ionic interactions at high salinities; and (3) supersaturation of the brine with respect to dolomite (Folk and Land, 1975). At many DSDP sites in the deep ocean, well away from present or past sources of fresh or meteoric waters, the chemical composition of the interstitial fluid varies with depth from normal sea water to chemically modified compositions resulting from 


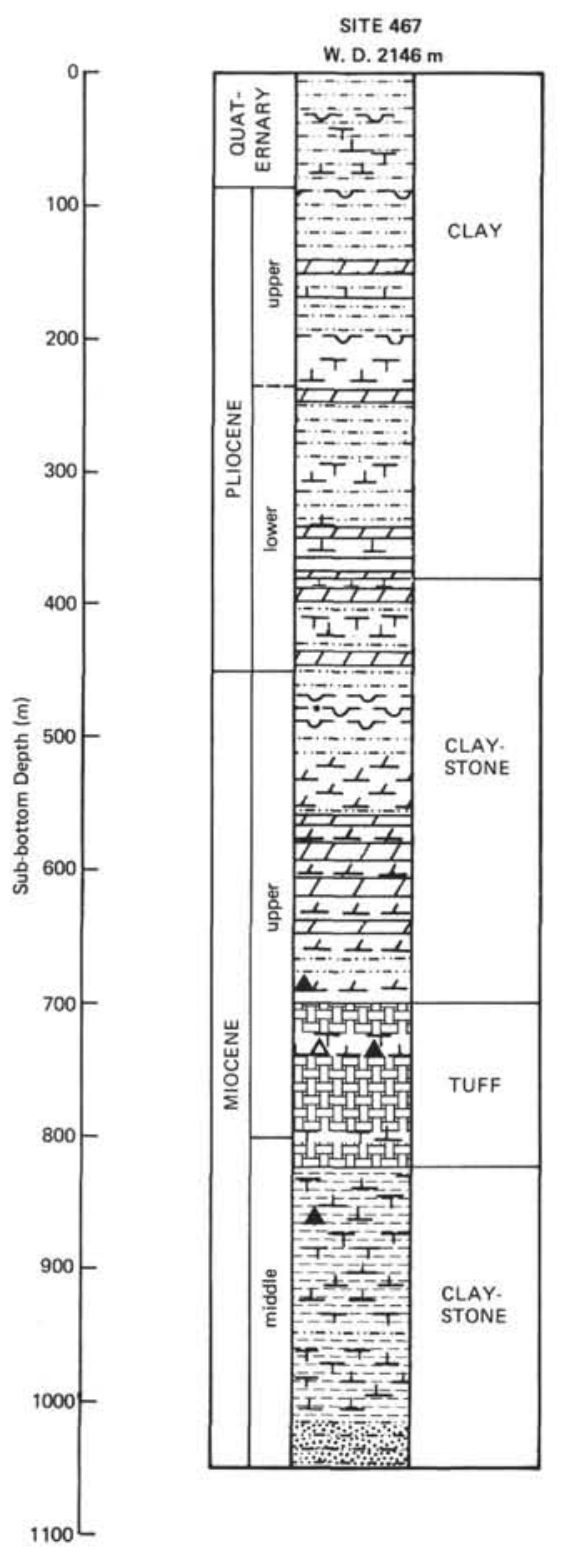

CALIFORNIA CONTINENTAL BORDERLAND
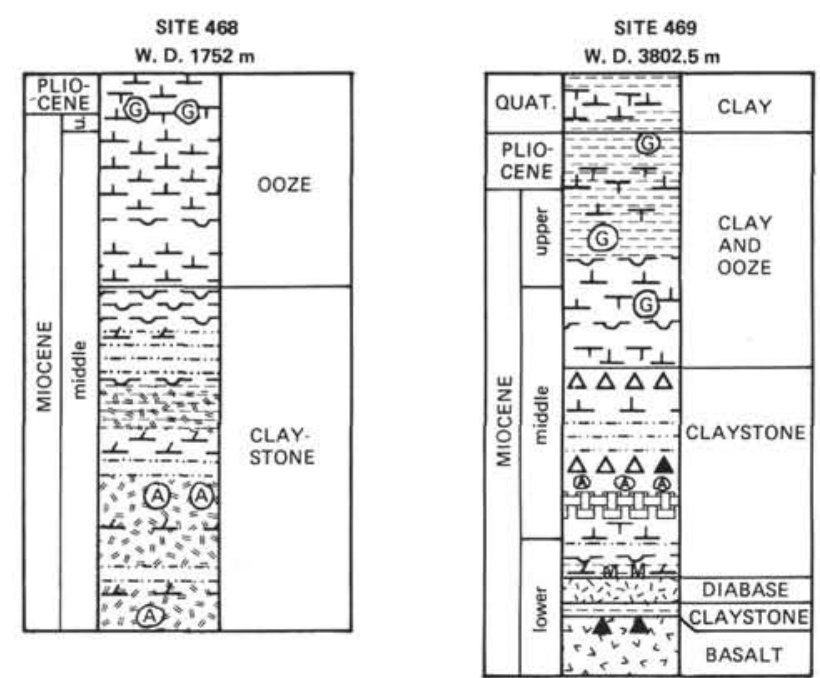

Figure 2. Lithologic and stratigraphic summary of Leg 63 sites showing distribution of authigenic carbonates and associated lithofacies.

diagenetic reactions in the sediment (e.g., Sayles and Manheim, 1975) and/or from alteration of volcanic matter and basalts (e.g., Lawrence et al., 1975). The $\mathrm{Mg} / \mathrm{Ca}$ molar ratio of this water varies from a sea-water value of 5 to an $\mathrm{Mg}$-depleted value of 1 or slightly less over about a kilometer of burial. The $\mathrm{Mg}$ depletion is sometimes ascribed to dolomitization of biogenic carbonate in the sediment (Sayles and Manheim, 1975). Elevated temperatures associated with burial (Rosenberg et al., 1967; Usdowski, 1968) and the presence of certain organic acids derived from the microbial decomposition of organic matter (Kitano and Kanamori, 1966) apparently promote dolomitization of pre-existing calcite by reducing the degree of hydration of magnesium, thereby facilitating entry of these ions into the calcite structure.
Microbial decay of organic matter in sediments at low temperatures associated with shallow burial $(<\sim 100 \mathrm{~m})$ can significantly alter the composition of interstitial waters (Siever et al., 1965). In anaerobic marine environments specific reactions at shallow burial depths include bacterial reduction of sulfate in the oxidation of organic matter and reduction of $\mathrm{CO}_{2}$ to methane (Table 2 and references therein). The latter reaction occurs only after reduction of sulfate is complete (Nissenbaum et al., 1972; Claypool et al., 1973). These organic degradation processes are significant because they produce bicarbonate that both affects the solubility of existing calcite and contributes carbonate ions for incorporation in and direct precipitation of authigenic carbonates including dolomite (e.g., Sass and Kolodny, 1972). The organic carbon released and then 


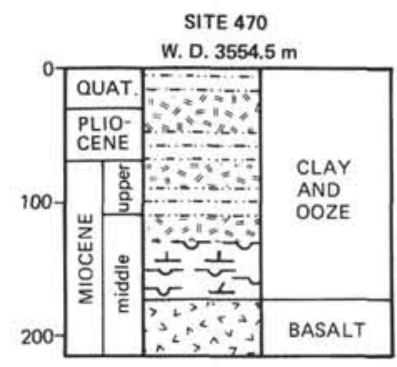

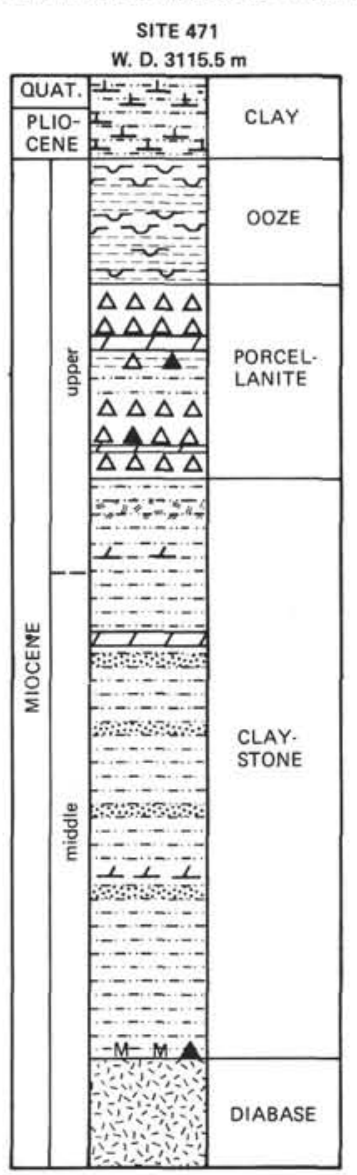
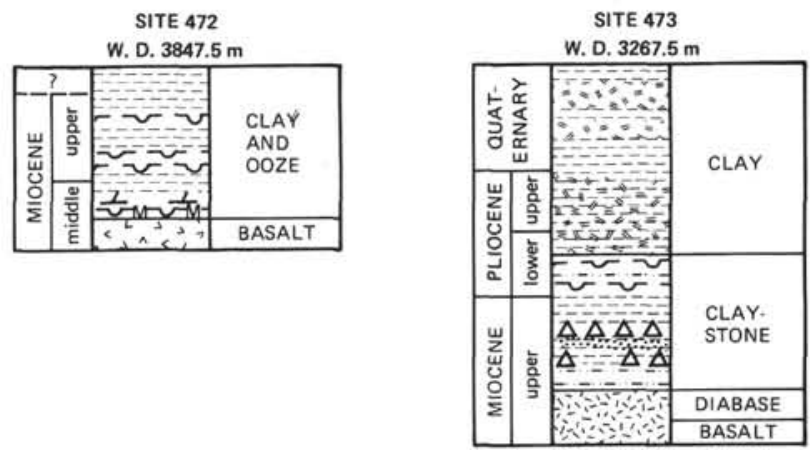

LEGEND

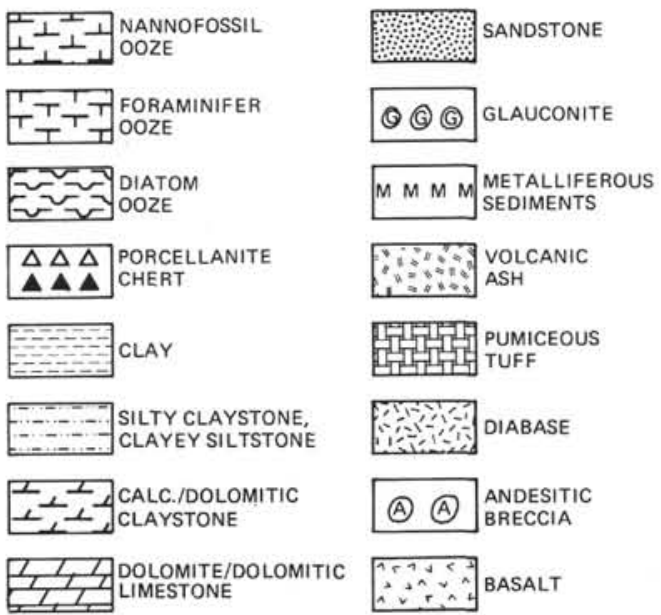

Figure 2. (Continued).

combined in these authigenic carbonates has a distinct isotopic signature (Table 2 and following section).

The lithologic and textural data presented in Figures 3 and 4 include the perfect preservation of primary sedimentary structures and the inclusion of unaltered calcareous and siliceous microfossils in dolomitic intervals. These data argue that dolomites at Sites 467,468 and 471 formed as cements and impregnations of organicrich sediments via direct precipitation from pore waters rather than as products of dolomitization of existing carbonates. At Site 467 a distinct alkalinity maximum is associated with the shallowest dolomite occurrence (Fig. 5). In addition, the absence of sulfate in interstitial waters, and abundant methane, framboidal pyrite, and organic carbon reported from cores taken below 70 meters at this site (Fig. 5 and references therein) indi- cate advanced anaerobic oxidation of organic matter through microbial reduction of sulfate to the point of methane production (e.g., Claypool and Kaplan, 1974). Supersaturation of pore waters could result in precipitation of dolomite according to reaction III in Table 2 . The subsurface chemical environment at Site 471 is somewhat similar to that at Site 467 , although the zone of high alkalinity is missing; the shallowest significant methane occurrence at this site is at about 350 to 400 meters (Fig. 5). At Site 468 neither high alkalinities nor significant methane values were encountered in the subsurface.

The scattered dolomite rhombs in sediments associated with igneous rocks at Sites 469,470 , and 472 may be primary precipitates, although, in contrast to Sites 467,468 , and 471 , the associated pore waters may have 


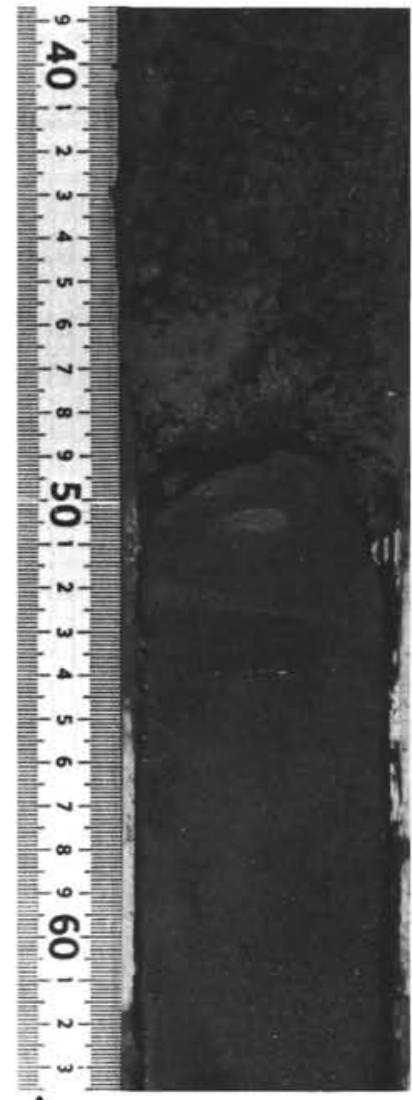

A

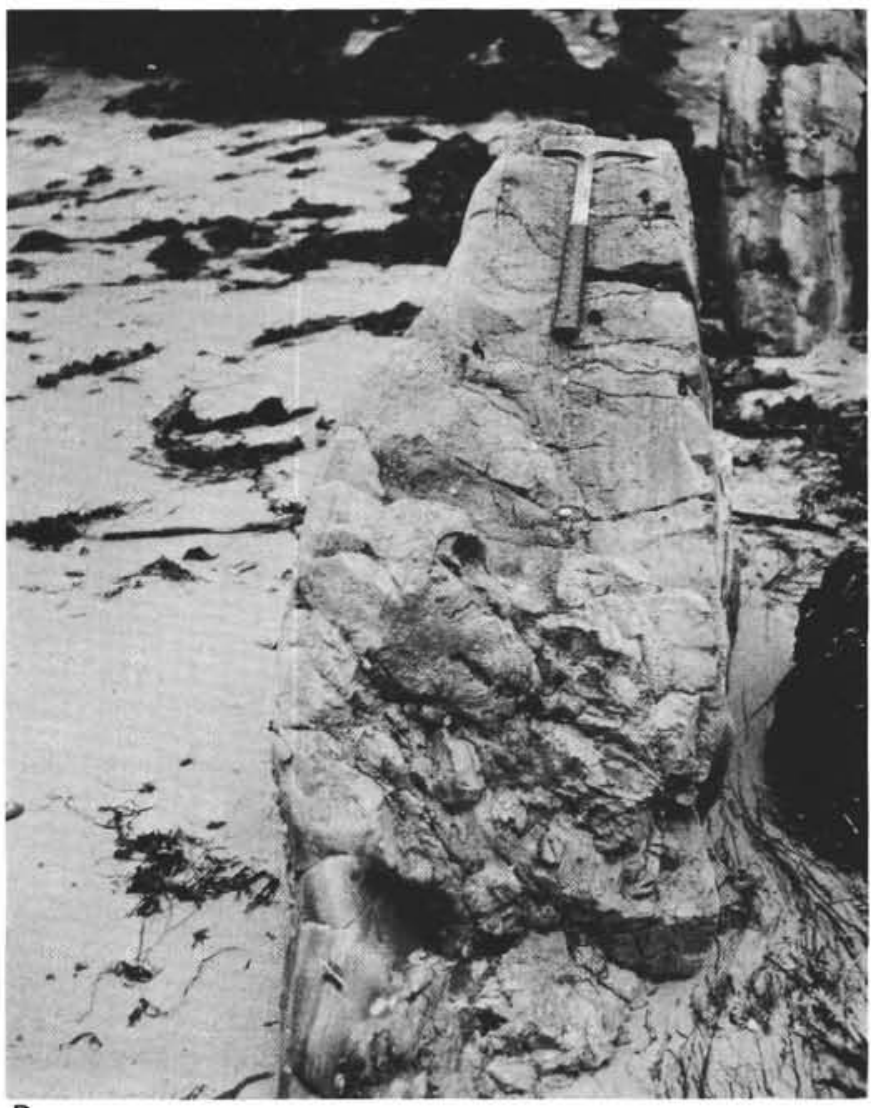

B
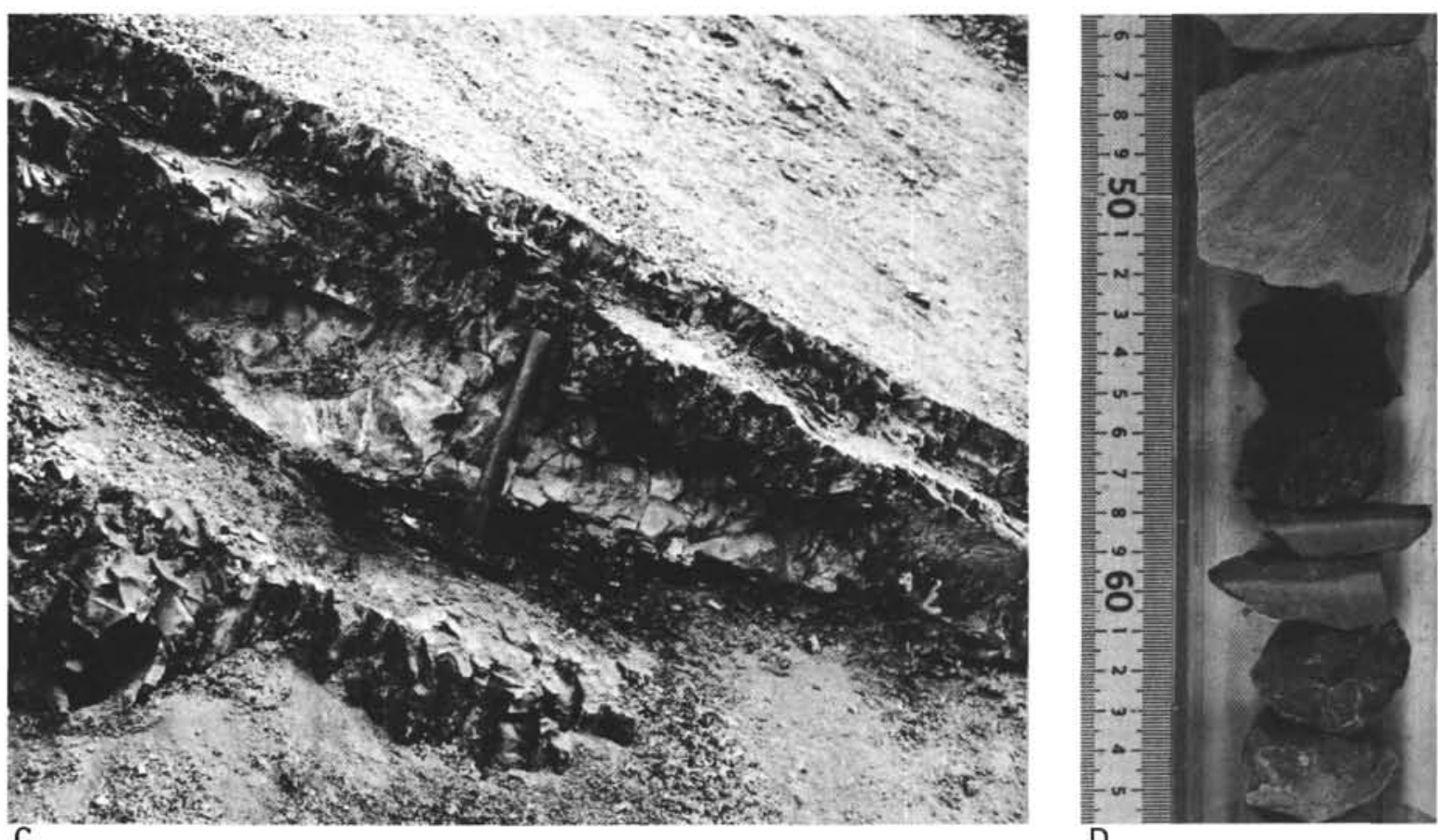

Figure 3. Leg 63 authigenic carbonates and similar rocks in Neogene siliceous rocks in Japan and California. A. Pliocene dolomitic limestone occurrence at Site 467 showing contrast between well-cemented carbonate interval and soft diatomaceous clay homogenized by the drilling process. Slabbed surface of dolomitic limestone shows abundant burrows; degree of cementation decreases toward the top of the coherent interval (Core 33, $304 \mathrm{~m}$ ). Meter stick for scale. B. Concretionary dolomite in siliceous rocks of the Miocene Monterey Shale, central California. Dolomite encloses several marine mammal vertabrae. C. Dolomitic concretion in Miocene chert and porcellanite of the Onnagawa Formation, northern Honshu. D. Massive Miocene dolomite (light interval in top of photo) in porcellanite (dark fragments) at Site 471 . Note enhanced recovery of dolomite relative to porcellanite (Core 21, $191 \mathrm{~m})$. Meter stick for scale. 
Table 1. Stratigraphic, compositional, and isotopic data for Leg 63 carbonates.

\begin{tabular}{|c|c|c|c|c|c|c|c|c|}
\hline $\begin{array}{c}\text { Sample } \\
\text { (interval in } \mathrm{cm} \text { ) }\end{array}$ & $\begin{array}{c}\text { Age of } \\
\text { Enclosing Sediment }\end{array}$ & $\begin{array}{l}\text { Depth below } \\
\text { Sea Floor } \\
\text { (m) }\end{array}$ & $\begin{array}{l}\delta C^{13 .} \\
(\% \in \mathrm{PDB})\end{array}$ & $\begin{array}{c}{ }^{8 O^{18 *}} \\
(\% \mathrm{SMOW})\end{array}$ & $\begin{array}{c}\text { Total } \\
\text { Organic } \\
\text { Carbon } \\
(\%)\end{array}$ & $\begin{array}{l}\mathrm{MgCO}_{3} \text { in } \\
\text { Dolomite } \\
\text { (mole \%) }\end{array}$ & $\begin{array}{l}\mathrm{MgCO}_{3} \text { in } \\
\text { Calcite } \\
\text { (mole \%) }\end{array}$ & Lithology \\
\hline $467-16, \mathrm{CC}$ & late Pliocene ( $2 \mathrm{Ma})$ & 148 & 15.3 & 34.3 & 1.5 & 47 & $-^{b}$ & Clayey dolomite; no calcite. \\
\hline $467-17-1,8-11$ & late Pliocene ( $-2 \mathrm{Ma})$ & 148 & $15.8^{*}$ & $35.5^{*}$ & 1.3 & 49 & - & Clayey dolomite; minor calcite. \\
\hline $467-23-1,0-8$ & late Pliocene $(-2-3 \mathrm{Ma})$ & 206 & 13.6 (avg) ${ }^{*}$ & 31.8 (avg) ${ }^{*}$ & 0.8 & 46 & - & Clayey dolomite; minor calcite. \\
\hline $467-26-3,70-77$ & late Pliocene ( 2-3 Ma) & 241 & $13.6^{*}$ & $34.5^{*}$ & 1.7 & 47 & - & Clayey dolomite; minor calcite. \\
\hline $467-33-3,79-84$ & early Pliocene ( $\sim 4 \mathrm{Ma})$ & 304 & $12.2^{*}$ & $31.9^{*}$ & 1.5 & 46 & 1 & $\begin{array}{l}\text { Clayey dolomitic limestone; } \\
\text { calcite > dolomite. }\end{array}$ \\
\hline $467-36-4,7-13$ & early Pliocene ( $-4-5 \mathrm{Ma})$ & 334 & $11.4^{*}$ & $32.1^{*}$ & 2.1 & 45 & - & Clayey dolomite; minor calcite. \\
\hline $467-40-1,81-85$ & early Pliocene ( $\sim 4-5 \mathrm{Ma})$ & 368 & $8.4^{*}$ & $33.7^{*}$ & 1.6 & 45 & 1 & $\begin{array}{l}\text { Clayey calcareous dolomite; } \\
\text { dolomite }>\text { calcite. }\end{array}$ \\
\hline $467-41-3,33-42$ & early Pliocene ( 4-5 Ma) & 381 & $8.6^{*}$ & $33.9^{*}$ & 5.3 & 45 & 0 & $\begin{array}{l}\text { Clayey calcareous dolomite; } \\
\text { dolomite > calcite. }\end{array}$ \\
\hline $467-48-1,57-63$ & late Miocene ( $\sim-6 \mathrm{Ma})$ & 444 & $9.7^{*}$ & $31.3^{*}$ & 1.1 & 47 & 2.5 & $\begin{array}{l}\text { Clayey calcareous dolomite; } \\
\text { dolomite }>\text { calcite. }\end{array}$ \\
\hline $467-67-1,35-41$ & late Miocene ( $8-9 \mathrm{Ma})$ & 624 & 7.0 & 29.4 & 0.5 & 44 & - & Clayey dolomite \\
\hline $467-67-1,100-104$ & late Miocene $(\sim 8-9 \mathrm{Ma})$ & 625 & $-3.6^{*}$ & $27.8^{*}$ & 1.4 & 46 & 4 & $\begin{array}{l}\text { Clayey calcareous dolomite; } \\
\text { dolomite > calcite. }\end{array}$ \\
\hline $467-69-2,15-20$ & late Miocene ( -9-10 Ma) & 644 & $1.8^{*}$ & $28.1^{\circ}$ & 2.7 & 47 & 2.5 & $\begin{array}{l}\text { Siliceous calcareous/dolomitic } \\
\text { claystone; dolomite = calcite. }\end{array}$ \\
\hline $467-77-2,10-17$ & late Miocene $(\sim 10-11 \mathrm{Ma})$ & 720 & -1.6 & 29.6 & 1.3 & - & 2 & Nannofossil claystone; no dolomite. \\
\hline $467-92-1,36-52$ & middle Miocene $(-13-14 \mathrm{Ma})$ & 861 & 0.2 (avg) & 27.8 (avg) & 2.1 & - & 1 & Nannofossil claystone; no dolomite. \\
\hline $467-94-1,54-58$ & middle Miocene ( - 13-14 Ma) & 881 & $-4.7^{*}$ & $31.4^{\circ}$ & 0.9 & 46 & 1 & $\begin{array}{l}\text { Clayey dolomitic nannofossil } \\
\text { chalk; calcite }>\text { dolomite. }\end{array}$ \\
\hline $468-21-1,32-34$ & middle Miocene ( - $16 \mathrm{Ma})$ & 184 & 0.8 & 33.3 & 1.1 & 49 & - & $\begin{array}{l}\text { Dolomitic silty claystone; no } \\
\text { calcite. }\end{array}$ \\
\hline $468 \mathrm{~B}-20, \mathrm{CC}$ & middle Miocene ( 16 Ma) & 245 & 0.1 & 32.1 & 1.2 & 47 & - & $\begin{array}{l}\text { Dolomitic silty claystone associated } \\
\text { with volcaniclastics; no calcite. }\end{array}$ \\
\hline $468 \mathrm{~B}-27-1,7-10$ & early-middle Miocene ( - 16-17 Ma) & 311 & 0.9 & 30.5 & 0.6 & 46 & - & $\begin{array}{l}\text { Dolomitic silty claystone associated } \\
\text { with volcaniclastics; no calcite. }\end{array}$ \\
\hline 468B-34-1, 3-7 & early Miocene ( $-17-18 \mathrm{Ma})$ & 378 & -5.6 & 29.9 & n.d. ${ }^{a}$ & 47 & - & $\begin{array}{l}\text { Dolomitic silty claystone associated } \\
\text { with volcaniclastics; no calcite. }\end{array}$ \\
\hline $471-20-1,15-17$ & late Miocene ( 9-10 Ma) & 180 & -23.2 (avg) & 29.4(avg) & 0.2 & 48 & - & $\begin{array}{l}\text { Clayey siliceous dolomite; no } \\
\text { calcite. }\end{array}$ \\
\hline $471-21-1,37-39$ & late Miocene ( - 9-10 Ma) & 190 & -29.8 & 28.8 & 0.2 & 51 & - & $\begin{array}{l}\text { Clayey siliceous dolomite; no } \\
\text { calcite. }\end{array}$ \\
\hline $471-22-1,18-19$ & late Miocene $(\sim 9-10 \mathrm{Ma})$ & 200 & -17.6 & 30.5 & 0.7 & n.d. & - & Dolomitic porcellanite; no calcite. \\
\hline $471-31-1,98-107$ & late-middle Miocene ( $-11-12 \mathrm{Ma})$ & 286 & -5.9 & 31.2 & 0.4 & 48 & 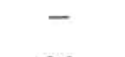 & $\begin{array}{l}\text { Clayey siliceous dolomite; no } \\
\text { calcite. }\end{array}$ \\
\hline $471-37, \mathrm{CC}$ & middle Miocene ( 12-13 Ma) & 345 & -9.6 & 20.7 & 0.1 & - & 2.5 & Clayey limestone; no dolomite. \\
\hline $471-39-4,6-10$ & middle Miocene $(-13-14 \mathrm{Ma})$ & 366 & 0.8 & 27.2 & n.d. & 45 & & $\begin{array}{l}\text { Dolomitic silty claystone; no } \\
\text { calcite. }\end{array}$ \\
\hline $471-64-3,82-85$ & middle Miocene ( - 14-15 Ma) & 602 & $-3.3^{*}$ & $31.9^{*}$ & n.d. & - & 2.5 & $\begin{array}{l}\text { Dolomitic/calcareous silty claystone; } \\
\text { calcite }>\text { dolomite. }\end{array}$ \\
\hline
\end{tabular}

Note: - An asterisk following $\delta \mathrm{C}^{13}$ and $\delta \mathrm{O}^{18}$ values indicates samples in which calcite was removed by repeated treatment with $0.1 \mathrm{M}$ acetic acid before measurement of isotopic composition. The isotopic values listed, therefore, refer only to the dolomite in the sample. position. The isotopic valuc
a n.d. = no data available.

a n.d. $=$ no data available.
- indicates either no dolomite or calcite or only minor calcite present.

been hydrothermally influenced (e.g., Thompson et al., 1968).

\section{Isotopes}

Carbon and oxygen isotopic compositions of Leg 63 diagenetic dolomites lie mostly within the observed field for "organically derived" dolomites (Fig. 6). Although the single authigenic calcite analyzed (Sample 471$37, \mathrm{CC})$ falls within the fresh-water limestone field in this diagram, it matches reported isotopic values for organically derived calcites from the southern Bering Sea (Hein et al., 1979). Two nannofossil claystones (calcite) lie well within the range of marine limestone.

\section{Oxygen Isotopes-A Crude Thermometer}

Unlike the well-known calcite-water fractionation (O'Neil et al., 1969), the isotopic fractionation between dolomite and water at low temperatures is still rather uncertain. Temperatures of formation of dolomite may be estimated from its oxygen isotopic composition by using experimental dolomite-water or protodolomitewater fractionation expressions (Fig. 7) or by subtracting $0.06 \%$ o per mole $\% \mathrm{MgCO}_{3}$ from the observed $\delta \mathrm{O}^{18}$ value of dolomite (Tarutani et al., 1969) and then using the calcite-water fractionation. We used the experimental protodolomite-water fractionation expression (curve $c$ in Fig. 7) to estimate temperatures of formation of Leg 63 dolomites because: (1) the range in experimental temperatures for this expression is $25^{\circ} \mathrm{C}$ to $79^{\circ} \mathrm{C}$, making it more reliable than curves extrapolated from high temperatures; (2) this expression agrees with extrapolations of more recently determined dolomite-water fractionations (e.g., Sheppard and Schwarcz, 1970 [computed from dolomite-calcite fractionation]; Matthews and Katz, 1977 [curve $b$ in Fig. 7]); and (3) the constant offset of about $3.1 \%$ from the calcite-water fractionation is about what one would predict using the correction of $0.06 \%$ o per mole $\% \mathrm{MgCO}_{3}$ for the magnesium content of the Leg 63 dolomites (Table 1). For calcite samples we computed isotopic temperatures using the calcite-water fractionation (O'Neil et al., 1969; curve $a$ in Fig. 7). In addition we assumed all carbonates equilibrated with fluid having $\delta \mathrm{O}^{18}=0.0 \%$ SMOW. This assumption yields maximum formation temperatures, because many $\delta \mathrm{O}^{18}$ profiles of interstitial waters at DSDP sites begin at $0 \%$ near the sediment/ water interface and show an average depletion gradient of about $-0.5 \% / 100$ meters of burial (e.g., Lawrence et 

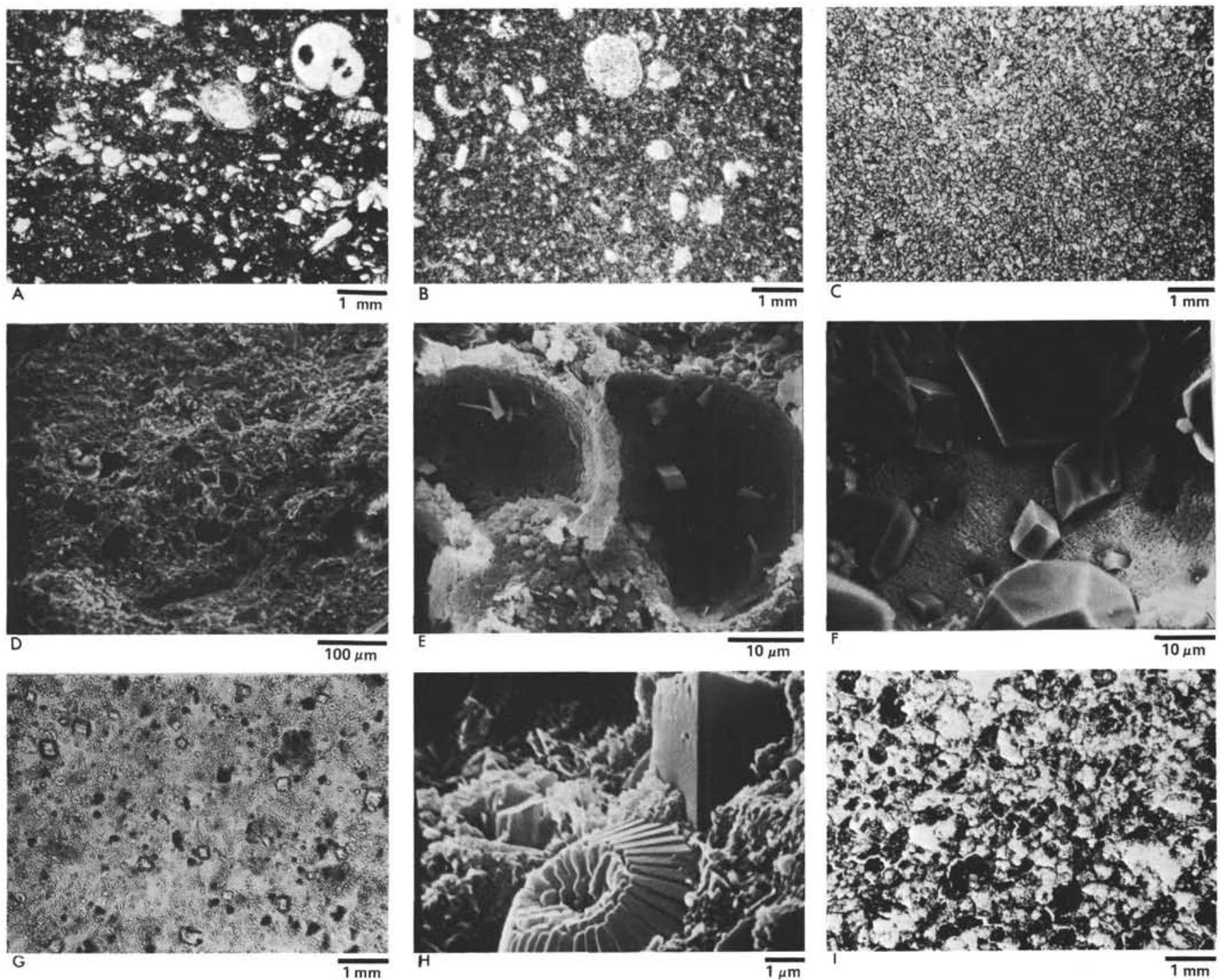

Figure 4. Microtextures of Leg 63 authigenic carbonates. A. Thin-section photomicrograph (plane light) of dolomitic, silty claystone at Site 468. Dolomite occurs as scattered crystals with unaltered foraminifers in a silty matrix (Sample 468B-22,CC). B. Thin-section photomicrograph (plane light) of dolomite at Site 467. Cementation is more complete than in A, although scattered detrital grains and dolomite-filled microfossils are present (Sample 467-24-1, $10 \mathrm{~cm}$ ). C. Thin-section photomicrograph of dolomite at Site 471 showing advanced degree of cementation. Siliceous mud is completely cemented with equant dolomite crystals (Sample 471-20-1, 15-17 cm). D. SEM of dolomitic claystone of Site 467 showing typical overall composition and texture. Original detrital constituents-diatoms, foraminifers, sponge spicules, quartz, and feldspar and clay-have been cemented with fine-grained dolomite (Sample 467-23-1, 0-8). E. SEM close-up of foraminifer in D. Test is well-preserved but contains intrachamber crystal growths of clinoptilolite(?) and rhombic dolomite. F. SEM photograph of interior of foraminifer test chamber showing crystal growths of analcime, dolomite, and perhaps some salt but very little alteration of the test itself (Sample 467-33-3, 79-84). G. Smear-slide photomicrograph (plane light) of dolomitic claystone at Site 472. Dolomite rhombs and unaltered coccoliths peacefully coexist (Sample 472-12-2, 54-55 cm). H. SEM photo of dolomitic nannofossil claystone at Site 467 showing relationship similar to that in G. Large prismatic crystal is dolomite (Sample 467-69-2, 15-20). I. Thin-section photomicrograph (plane light) of diagenetic limestone at Site 471. Large calcite grains (light areas) have ragged edges and fragmental appearance; dark patches are mostly clay (Sample 471-37,CC).

al., 1975). Each $-0.5 \% \delta \mathrm{O}_{\mathrm{H}_{2} \mathrm{O}}^{18}$ depletion would decrease the computed formation temperature by about $2.5^{\circ} \mathrm{C}$.

With some exceptions, isotopic temperatures of formation of dolomites at Sites 467,468 , and 469 match or are less than present subsurface temperatures computed from present thermal gradients and bottom-water temperatures (Tables 3 and 4 ). If the dolomite thermometer is correct and if thermal gradients have remained temporally constant, then the results suggest that most Leg 63 dolomites formed at their present depths of burial or at somewhat shallower depths. Assuming constant thermal gradients and homogeneous isotopic compositions for dolomitic layers, we estimated formation depths from the isotopic temperatures (Table 3 ). The range is 87 to 658 meters and matches that reported by Hein et al. (1979) for authigenic carbonates in sediments of the southern Bering Sea. Using these depths and sedimentation rate curves for each site (see site chapters in this volume), we estimated the age or time of formation of each sample (Fig. 8). The results suggest a wide time range in dolomite formation at any single site. Hein et al. (1979) 


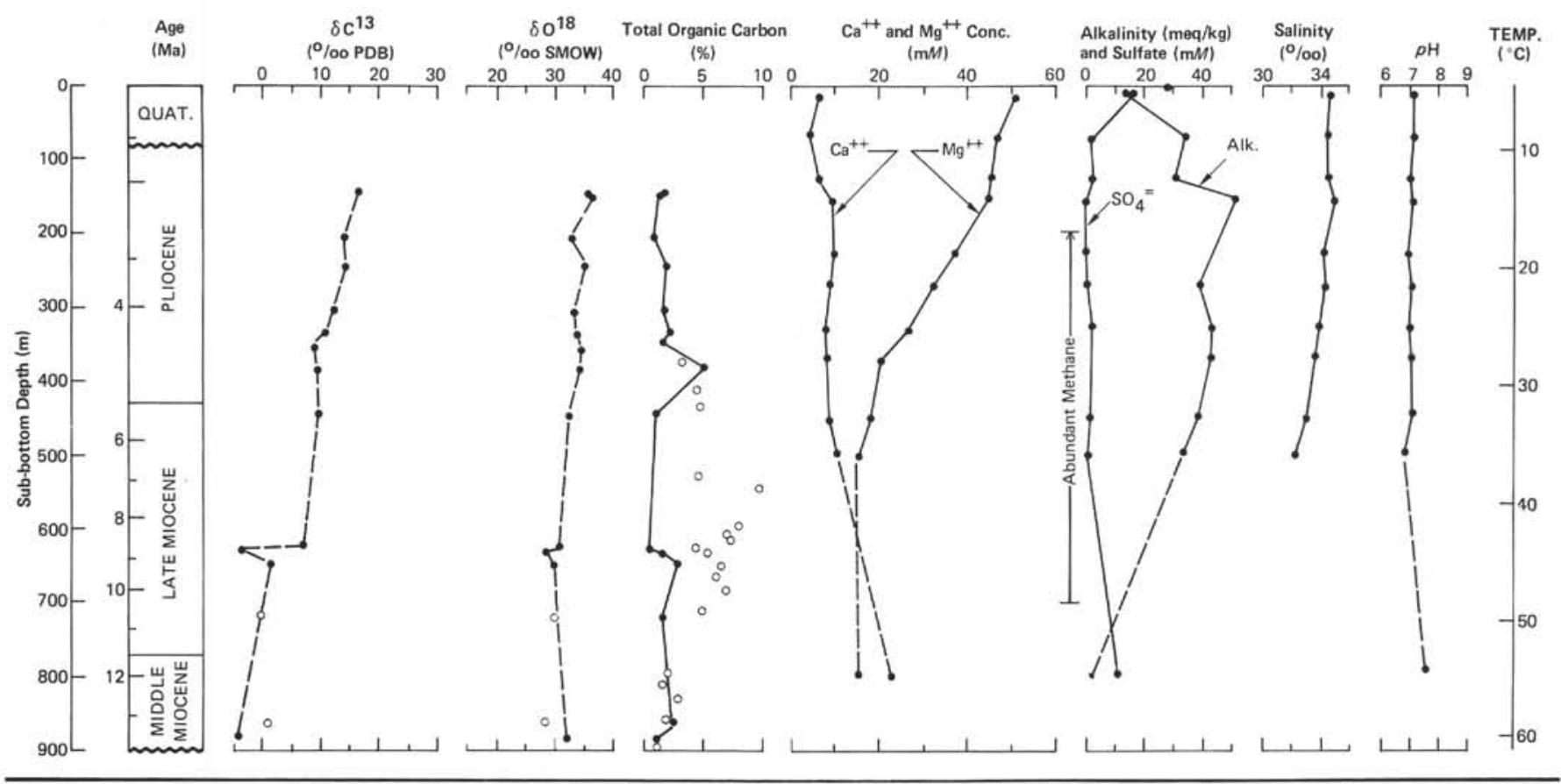

SITE 468
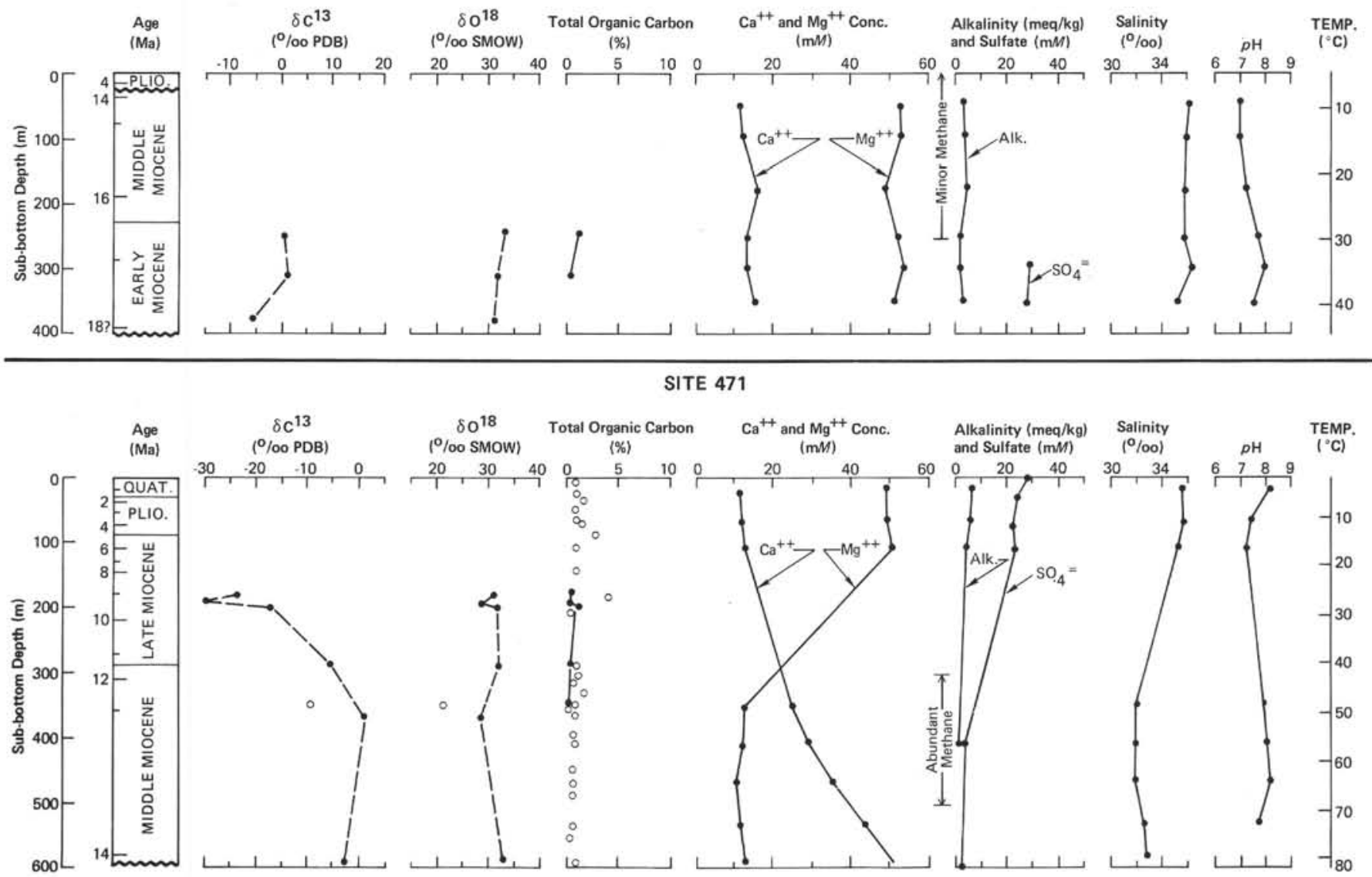

Figure 5. Summary of isotopic compositions, organic carbon contents, and interstitial water chemistry at Sites 467, 468, and 471. (Filled symbols in $\delta \mathrm{C}^{13}$ and $\delta \mathrm{O}^{18}$ profiles represent dolomites; open symbols are calcite. Filled symbols in organic carbon profiles represent carbonates; open symbols are associated sediments. Some interstitial water data is included from Gieskes et al. [this volume]. Methane occurrences are noted from shipboard reports and Whelan and Hunt [this volume].) 
Table 2. Diagenetic zones and oxidation-reduction reactions for subsurface microbial metabolic processes.

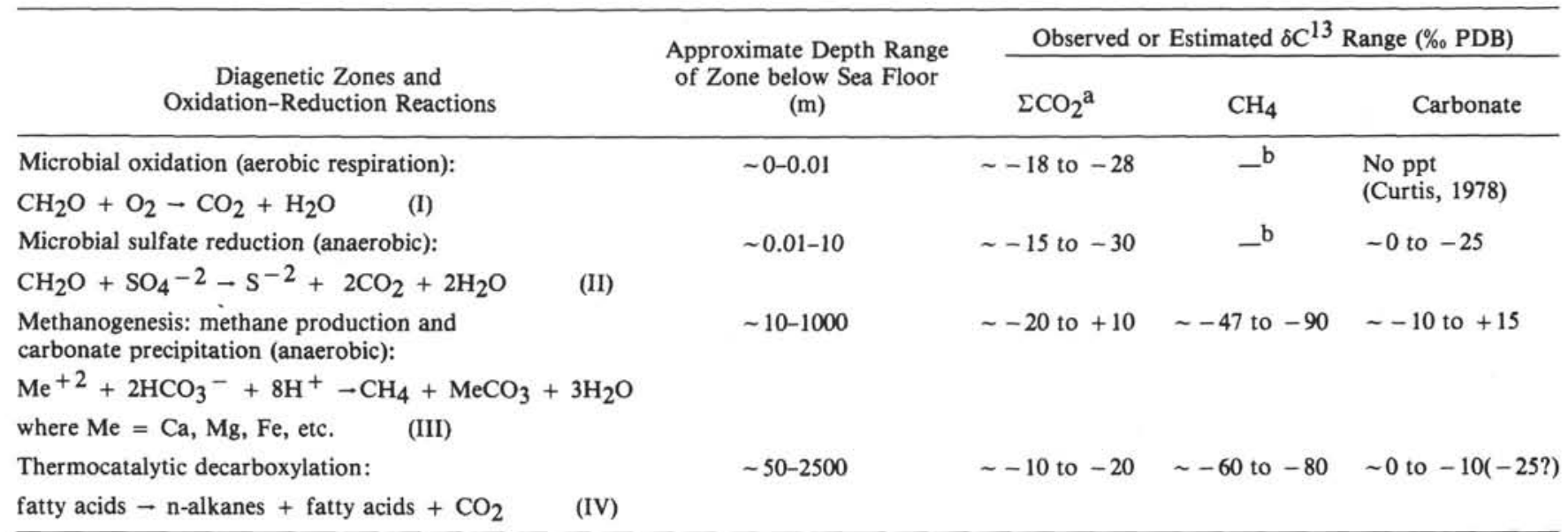

Note: Reactions, depth intervals, and isotopic data compiled from Cooper and Bray (1963), Eisma and Jung (1969), Claypool et al. (1973), Claypool

(1974), Claypool and Kaplan (1974), Irwin et al. (1977), Curtis (1978), Hein et al. (1979).

a Total dissolved $\mathrm{CO}_{2}$, mainly as bicarbonate.

b Methane not present.

reached similar conclusions from their investigation of Bering Sea carbonates.

At Site 471 several dolomites, notably from Sections 471-20-1, 471-21-1, and 471-22-1, yield isotopic temperatures that exceed present subsurface temperatures by as much as $13^{\circ} \mathrm{C}$ (Table 3 ). This discrepancy amounts to a maximum uncertainty of about \pm 98 meters in calculated formation depths. If the isotopic temperatures are correct, this uncertainty may indicate a past gradient that was somewhat higher than present at this site. The temperature discrepancies may also reflect isotopic exchange between dolomite and $\mathrm{O}^{18}$-depleted water or, alternatively, istopic nonequilibrium during authigenic carbonate precipitation.

Perhaps more significant is the possibility that dolomites nucleate at one depth and then continue to grow with additional burial (Kelts and McKenzie, 1980). Observed chemical gradients across carbonate concretions (Raiswell, 1976) and $\delta \mathrm{O}^{18}$ excursions spanning as much as $10 \%$ across single dolomite beds (Kelts and McKenzie, 1980) emphasize the importance of this mode of growth. A $10 \%$ difference in $\delta \mathrm{O}^{18}$ between the top and bottom of a single bed translates to a temperature difference of about $50^{\circ} \mathrm{C}$. Thus formation temperatures and depths estimated from single measurements of dolomite zones in this study are approximations that may integrate isotopic effects of precipitation over a range of temperatures.

\section{Carbon Isotopes-An Index of Organic Matter Decay}

Carbon isotopes of authigenic carbonates precipitated within the various zones of microbial metabolic processes reflect the $\delta \mathrm{C}^{13}$ of the carbon species in those zones (e.g., Table 1 and Fig. 9). Negative $\delta \mathrm{C}^{13}$ carbonate values, as low as $-25 \%$, can derive from abundant light-carbon $\mathrm{CO}_{2}$ (as dissolved bicarbonate) in shallow zones of aerobic microbial oxidation and anaerobic sulfate reduction (Claypool, 1974; Claypool and Kaplan, 1974; Irwin et al., 1977; Curtis, 1978). More positive $\delta \mathrm{C}^{13}$ values, up to $+18 \%$ (Hein et al., 1979), occur below this zone where methane generation by $\mathrm{CO}_{2}$ reduction in microbial metabolic processes produces residual heavy-carbon bicarbonate in interstitial waters through preferential removal of $\mathrm{HC}^{12} \mathrm{O}_{3}^{-}$(Rosenfeld and Silverman, 1959; Claypool, 1974; Claypool and Kaplan, 1974). Commonly this trend toward $\delta C^{13}$ enrichment reverses at greater burial depths, perhaps because of the imbalance between the rates at which light-carbon $\mathrm{CO}_{2}$ is added and removed in methane production (Claypool, 1974). The latter trend could yield light-carbon carbonates $\left(\delta \mathrm{C}^{13} \simeq-10 \%\right.$ ) near the base of the zone of methanogenesis within the interval of thermocatalytic decarboxylation (e.g., Figure 9, Table 2; also see Curtis, 1978).

At Sites 467,468 and $471, \delta C^{13}$ values of dolomites generally decrease with increasing depths and temperatures of formation (Fig. 10). At Sites 467 and 468, both the magnitudes of the $\delta \mathrm{C}^{13}$ values and the direction of change suggest that these dolomites formed within the zone of methanogenesis (Zone III in Table 2 and Fig. 9). To evaluate the possibility that these dolomites might have formed in equilibrium with both $\mathrm{CO}_{2}$ and $\mathrm{CH}_{4}$ in this zone, we estimated equilibrium $\delta \mathrm{C}^{13}$ values of these gases graphically from Fig. 11 using the carbonate $\delta \mathrm{C}^{13}$ values and temperatures from $\delta \mathrm{O}^{18}$ data. The ranges in computed $\delta C^{13}$ values, $\mathrm{CO}_{2}=-17 \%$ to $0 \%$ and $\mathrm{CH}_{4}$ $=-82 \%_{0}$ to $-64 \%_{0}$ (Table 3 ), are well within the observed ranges typical of the zone of methanogenesis (Table 2), lending further support to the inference that these dolomites did indeed form within the zone of methane production.

The $\delta C^{13}$ depth and temperature trends at Site 471 are similar to those at Sites 467 and 468 (Fig. 10); however, three dolomites (from Sections 471-20-1, 471-21-1, and 471-22-1; Table 1) have extremely negative values that match or are lighter than the most negative values suggested for the zones of carbonate reduction or decarboxylation (Zones III and IV in Table 2; also see Irwin 


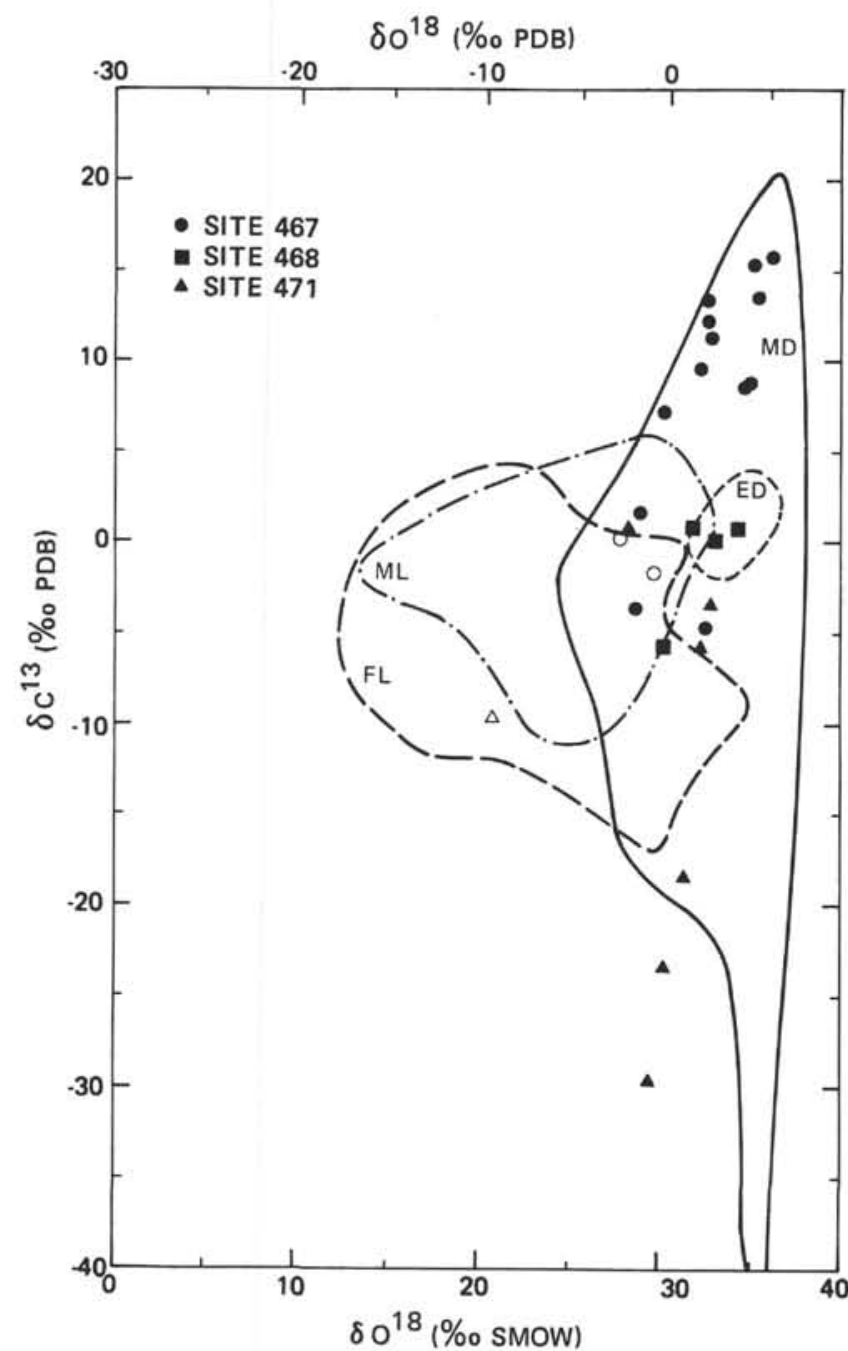

Figure 6. Carbon and oxygen isotopes of Leg 63 authigenic carbonates and two nannofossil limestones (open circles). (Filled symbols are dolomites, open symbols are limestone or biogenic calcite. Compositional fields are: $\mathrm{ML}=$ marine limestone, $\mathrm{FL}=$ fresh water limestone, $\mathrm{ED}=$ evaporitic dolomites, $\mathrm{MD}=$ organically derived dolomites; these data are from Keith and Weber [1964], Milliman [1974], Murata et al. [1969], Irwin et al., [1977] and Hein et al. [1979; dolomites only].)

et al. [1977] and Curtis [1978]). In addition, computed $\delta \mathrm{C}^{13}$ equilibrium values for $\mathrm{CO}_{2}$ and $\mathrm{CH}_{4}$ associated with these dolomites fall outside the limits of observed values (Tables 2 and 3). These three light-carbon dolomites may have formed within the zone of sulfate reduction. If so, then their $\delta \mathrm{O}^{18}$ values may reflect either nonequilibrium exchange with pore waters or equilibrium with $\mathrm{O}^{18}$-depleted water.

DeGiovani et al. (1974) postulate that light-carbon dolomite may form in organic-poor sediment by direct oxidation of organic matter to $\mathrm{CO}_{2}$ whereas heavycarbon dolomites may precipitate in sediments with abundant organic matter where methane has been generated by $\mathrm{CO}_{2}$ reduction. Although there is not a direct correlation for individual samples, total organic carbon in heavy-carbon dolomites and associated sediments at Sites 467 and 468 is high, in the range $0.6 \%$ to

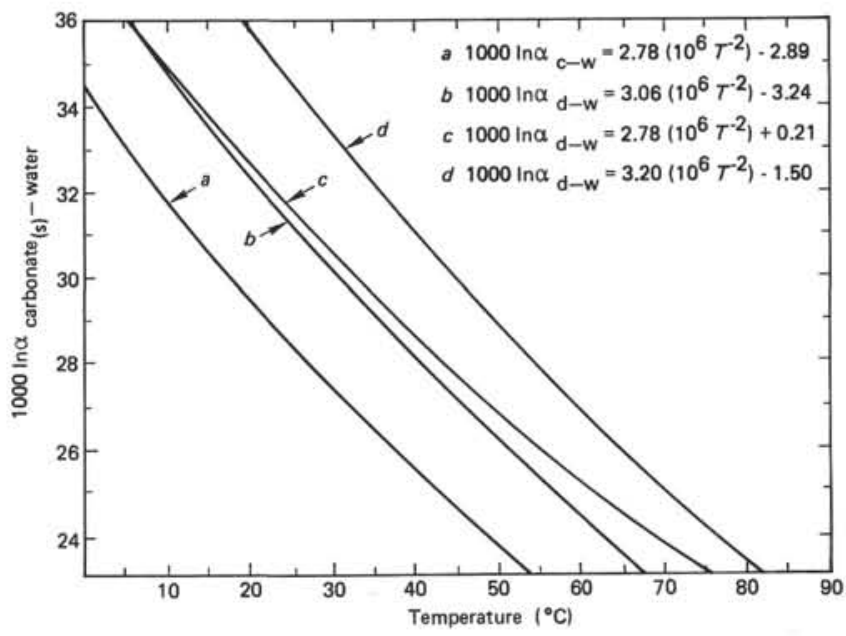

Figure 7. Experimentally determined fractionations of oxygen for calcite-water and dolomite-water ( $T$ in fractionation expressions is in ${ }^{\circ} \mathrm{K}$. Curve $a$ is calcite-water [O'Neil et al., 1969]; curve $b$ extrapolated dolomite-water [Matthews and Katz, 1977]; curve $c$ protodolomite-water [Fritz and Smith, 1970], using constant dolomite-calcite fractionation of $+3.1 \%$ given in Friedman and O'Neil [1977]; and curve $d$, extrapolated dolomite-water [Northrup and Clayton, 1966]. All expressions use 1.0412 for the fractionation factor for $\mathrm{CO}_{2}-\mathrm{H}_{2} \mathrm{O}$ at $25^{\circ} \mathrm{C}$ [Friedman and $\mathrm{O}$ 'Neil, 1977].)

9.5\%; values are relatively lower, between $0.5 \%$ and $1.0 \%$, at Site 471 where light-carbon dolomites occur (Table 1 and Fig. 5). Ultimately sedimentation rate may be the most important parameter influencing the timing, formation, and isotopic composition of authigenic carbonates in organic-rich sediments. Sedimentation rate controls both the preservation of organic matter and the extent of diffusion of oxygen and sulfate from overlying sea water into the sediment column. Slow rates of deposition would allow more complete oxidation of organic matter through aerobic pathways or anaerobic sulfate reduction, producing light-carbon carbonates; more rapid rates would inhibit diffusion of oxygen and sulfate in organic-rich sediment, promoting methanogenic processes and fostering heavier-carbon carbonates at shallow depths. Thermocatalytic decarboxylation could reverse this heavy-carbon isotopic trend perhaps through formation of abundant light-carbon $\mathrm{CO}_{2}$ in excess of the amount that can be removed by methane production (e.g., Claypool and Kaplan, 1974). A plot of $\delta C^{13}$ values of Leg 63 dolomites versus depositional rates of the enclosing sediments supports this relationship (Fig. 12). At Site 471 extremely light-carbon dolomites occur in sediments deposited at relatively low rates. More positive values at Sites 467 and 468 correspond to higher rates of sedimentation. The trend apparently reverses again to lighter values for dolomites in rapidly deposited sediments lower in the hole at Site 471 , which may reflect a later stage of decarboxylation.

\section{CONCLUSIONS AND IMPLICATIONS}

The significance of authigenic carbonate precipitation, particularly dolomite, in shallowly buried, organic-rich sediments deposited in productive areas along 
Table 3. Estimated depths and temperatures of formation for Leg 63 authigenic carbonates and computed $\delta \mathrm{C}^{13}$ equilibrium values for $\mathrm{CO}_{2}$ and $\mathrm{CH}_{4}$.

\begin{tabular}{|c|c|c|c|c|c|c|c|c|c|}
\hline $\begin{array}{l}\text { Sample } \\
\text { (interval in } \mathrm{cm} \text { ) }\end{array}$ & Mineralogy & $\begin{array}{l}\text { Present } \\
\text { Depth of } \\
\text { of Burial } \\
\text { (m) }\end{array}$ & $\begin{array}{c}\text { Present } \\
\text { Subsurface } \\
\text { Temperature } \\
\left({ }^{\circ} \mathrm{C}\right)\end{array}$ & $\begin{array}{c}\delta C^{13} \\
\text { Carbonate } \\
(\% \text { PDB) }\end{array}$ & $\begin{array}{c}\delta \mathrm{O}^{18} \\
\text { Carbonate } \\
(\% \text { SMOW) }\end{array}$ & $\begin{array}{c}\text { Estimated } \\
\text { Temperature } \\
\text { of Formation } \\
\left({ }^{\circ} \mathrm{C}\right)\end{array}$ & $\begin{array}{l}\text { Estimated } \\
\text { Depth } \\
\text { of Formation } \\
(\mathrm{m})\end{array}$ & $\begin{array}{c}\delta \mathrm{C}^{13} \\
\mathrm{CO}_{2} \\
(\% \circ \mathrm{PDB})\end{array}$ & $\begin{array}{c}\delta^{13} \\
\mathrm{CH}_{4} \\
(\% \circ \mathrm{PDB})\end{array}$ \\
\hline $467-17-1,8-11$ & dolomite & 148 & 14 & 15.8 & 35.5 & 10 & 87 & 2 & -72 \\
\hline $467-23-1,0-8$ & dolomite & 206 & 18 & 13.6 & 31.8 & 26 & 341 & 2 & -64 \\
\hline $467-26-3,70-77$ & dolomite & 241 & 20 & 13.6 & 34.5 & 14 & 151 & 0 & -72 \\
\hline $467-40-1,81-85$ & dolomite & 368 & 28 & 8.4 & 33.7 & 17 & 198 & -5 & -76 \\
\hline $467-41-3,33-42$ & dolomite & 381 & 29 & 8.6 & 33.9 & 17 & 198 & -5 & -76 \\
\hline $467-48-1,57-63$ & dolomite & 444 & 32 & 9.7 & 31.3 & 28 & 373 & -2 & -70 \\
\hline $467-67-1,35-41$ & dolomite & 624 & 44 & 7.0 & 29.4 & 38 & 531 & -4 & -68 \\
\hline $467-67-1,100-104$ & dolomite & 625 & 44 & -3.6 & 27.8 & 46 & 658 & -14 & -76 \\
\hline $467-69-2,15-20$ & dolomite & 644 & 45 & 1.8 & 28.1 & 45 & 642 & -9 & -74 \\
\hline $467-77-2,10-17$ & calcite & 720 & 50 & -1.6 & 29.6 & 21 & $--^{a}$ & - & - \\
\hline $468 \mathrm{~B}-34-1,3-7$ & dolomite & 378 & 42 & -5.6 & 29.9 & 35 & 305 & -17 & -82 \\
\hline $471-20-1,15-17$ & dolomite & 180 & 26 & -23.2 & 29.4 & 38 & 267 & -34 & -99 \\
\hline $471-21-1,37-39$ & dolomite & 190 & 28 & -29.8 & 28.8 & 41 & 289 & -40 & -104 \\
\hline $471-22-1,18-19$ & dolomite & 200 & 29 & -17.6 & 30.5 & 32 & 222 & -29 & -95 \\
\hline $471-31-1,98-107$ & dolomite & 286 & 41 & -5.9 & 31.2 & 29 & 200 & -18 & -84 \\
\hline $471-37, \mathrm{CC}$ & calcite & 345 & 49 & -9.6 & 20.7 & 72 & 519 & -16 & -71 \\
\hline $471-39-4,6-10$ & dolomite & 366 & 51 & 0.8 & 27.2 & 50 & 355 & -9 & -70 \\
\hline $471-64-3,82-85$ & dolomite & 602 & 83 & -3.3 & 31.9 & 25 & 170 & -16 & -84 \\
\hline
\end{tabular}

a $-=$ not applicable.

Table 4. Present thermal gradients and bottom-water temperatures at Sites 467, 468, and 471 .

\begin{tabular}{ccc}
\hline Site & $\begin{array}{c}\text { Measured or Estimated } \\
\text { Thermal Gradient } \\
\left({ }^{\circ} \mathrm{C} / \mathrm{km}\right)\end{array}$ & $\begin{array}{c}\text { Measured or Estimated } \\
\text { Bottom-Water Temperature } \\
\left({ }^{\circ} \mathrm{C}\right)\end{array}$ \\
\hline 467 & 63 & 4.5 \\
468 & 100 & 4.0 \\
471 & 133 & 2.0 \\
\hline
\end{tabular}

Note: Data are from site chapters (this volume). Values for Site 468 were estimated from positions of diagenetic silica zones (see Grechin et al., this volume).

continental margins and in small ocean basins is underscored by their widespread occurrence in Neogene and younger sediments in the Pacific region (e.g., Russell et al., 1967; Murata et al., 1969; Watanabe, 1970; Sawamura and Uemura, 1973; Claypool, 1974; Grechin, 1976; Hein et al., 1979; Friedman and Murata, 1979; Kelts and McKenzie, 1980; Moore and Gieskes, 1980), off the east coast of the U.S. (Hathaway and Degens, 1969; Deuser, 1970), in the Red Sea and Mediterranean regions (Supko et al., 1974; McKenzie et al., 1980), and in older units exposed on land (e.g., Murata et al., 1969; Sass and Kolodny, 1972; DeGiovani et al., 1974; Raiswell, 1976; Irwin et al., 1977).

Our investigation of authigenic carbonates recovered during Leg 63 drilling off southern California and Baja California suggests formative conditions of shallow burial and low temperature in association with carbon dioxide and methane produced by microbial breakdown

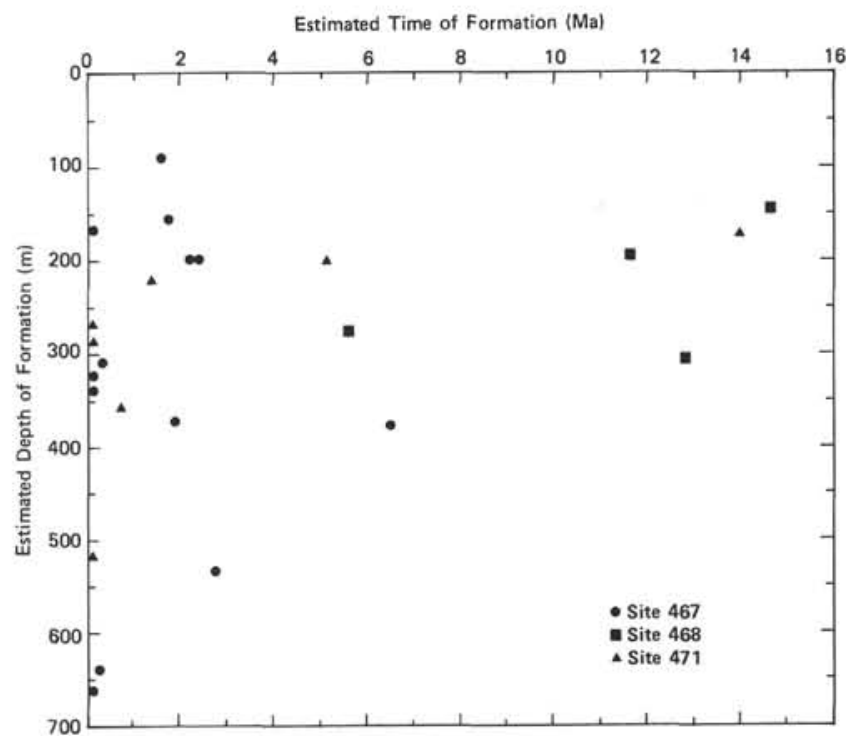

Figure 8. Estimated ages and depths of formation of Leg 63 dolomites. (See text for explanation.)

of organic matter. Most carbonates are dolomites containing 44 to 51 mole $\% \mathrm{MgCO}_{3}$. Well-preserved sedimentary structures and unaltered calcareous microfossils within many dolomitic intervals argue for cementation or impregnation of the enclosing fine-grained diatomaceous and siliceous sediments rather than replacement of pre-existing carbonate ooze or limestone. Interstitial water profiles suggest dolomite precipitates 


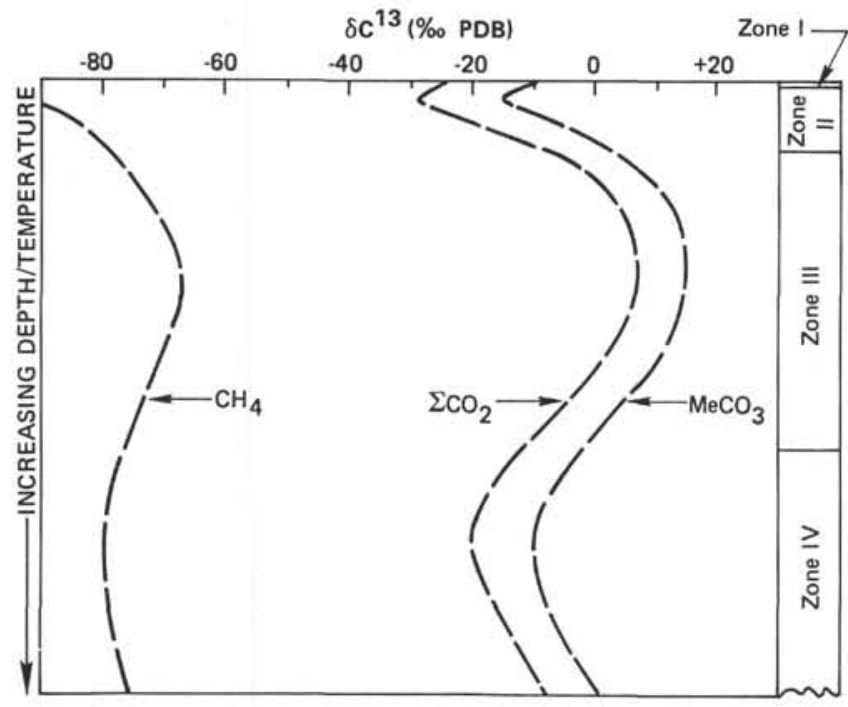

Figure 9. Schematic representation of expected $\delta C^{13}$ values of authigenic carbonates $\left(\mathrm{MeCO}_{3}\right.$, where $\mathrm{Me}=\mathrm{Ca}, \mathrm{Fe}, \mathrm{Mg}$, etc. $)$ for given isotopic ranges of $\mathrm{CH}_{4}$ and $\mathrm{\Sigma CO}_{2}$ in zones of progressive organic matter decay (see Table 2).
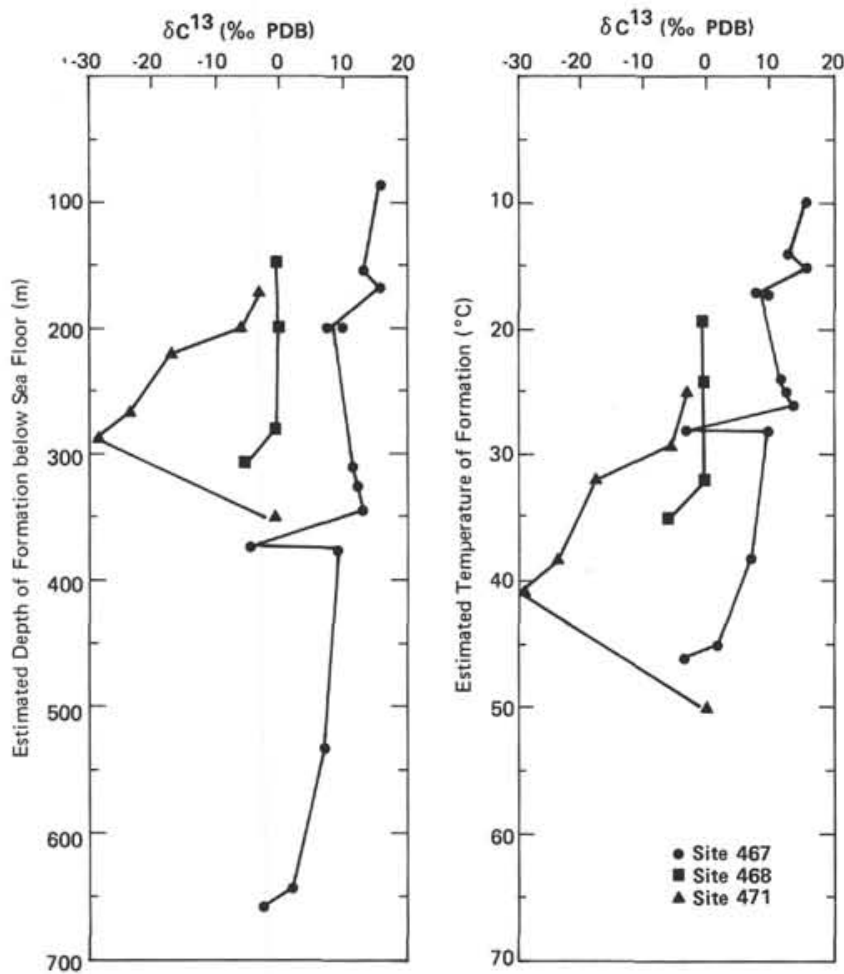

Figure 10. Carbon isotopes versus estimated time and temperature of formation of Leg 63 carbonates at Sites 467,468 , and 471 .

from water having $\mathrm{Mg} / \mathrm{Ca} \lesssim 5$ within zones of high alkalinity, the bicarbonate maxima resulting from production of abundant $\mathrm{CO}_{2}$ by microbial metabolism and/or thermal decarboxylation in the anaerobic decomposition of organic matter. Oxygen isotopes coupled with data on present thermal gradients at each site suggest a considerable range in temperatures, depths, and the timing of formation of these dolomites. Carbon

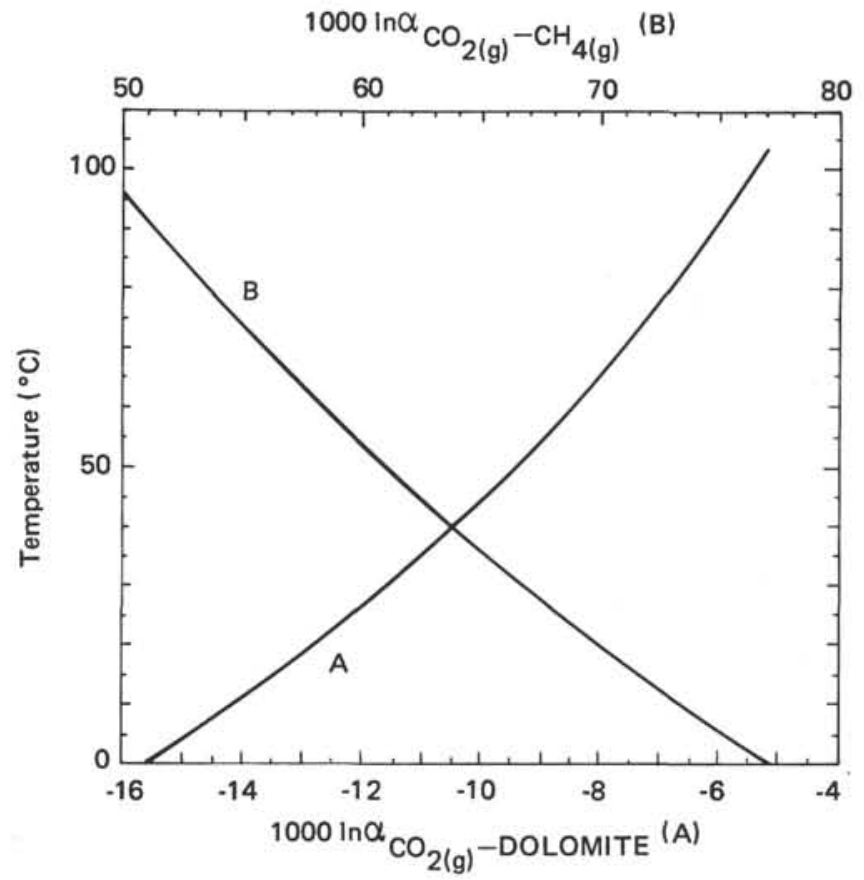

Figure 11. Fractionation curves of carbon for $\mathrm{CO}_{2}$ (gas)-dolomite (tentatively computed from $\mathrm{CO}_{2}$-calcite [Bottinga, 1968] and dolomite-calcite [Sheppard and Schwarcz, 1970]) and for $\mathrm{CO}_{2}$ (gas)- $\mathrm{CH}_{4}$ (gas) (Bottinga, 1969).

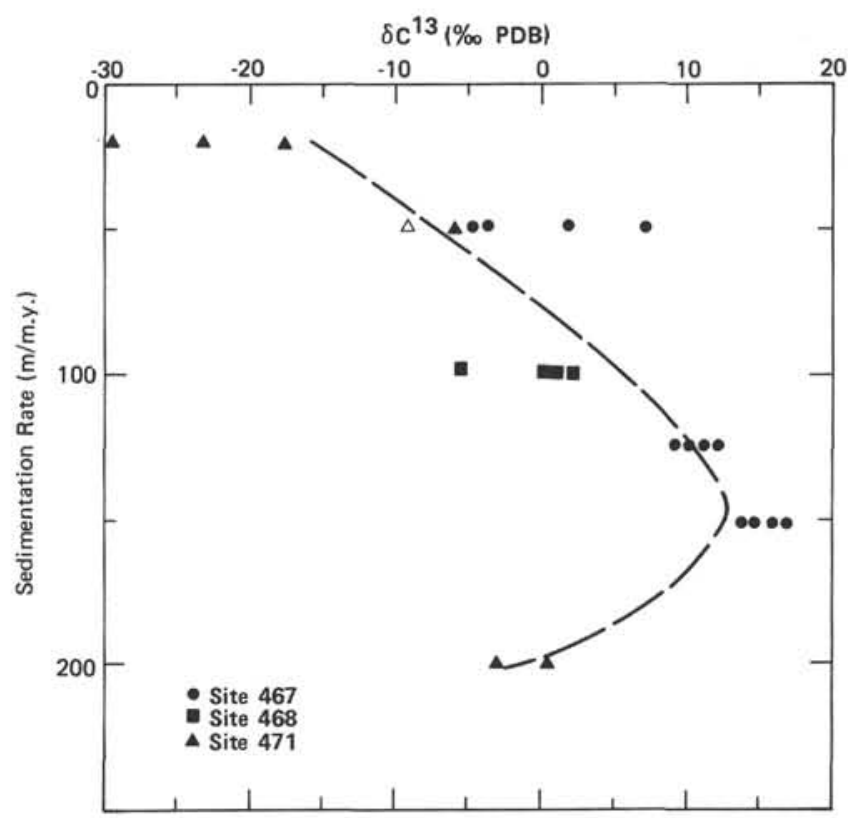

Figure 12. Carbon isotopes of Leg 63 carbonates versus sedimentation rates of the enclosing sediments at Site 467,468 , and 471 . (Filled symbols $=$ dolomite, open symbol $=$ diagenetic limestone.)

isotopes reflect dolomite formation within various subsurface zones of microbial decay of organic matter. Light-carbon dolomites, such as at Site 471 and perhaps Site 468 , may have precipitated in sediments containing little organic matter in shallow zones of aerobic oxidation and sulfate reduction. Dolomites occurring in 
organic-rich sediments at Site 467 have more positive values and may derive from $\mathrm{C}^{13}$ enriched bicarbonate in the zone of methane production. Ultimately sedimentation rate may dictate final isotopic compositions by controlling the preservation of organic matter and the extent of diffusion of oxygen and sulfate from overlying sea water into the sediment column; the latter process limits the depths of zones of organic matter diagenesis, particularly the depth of methane formation.

\section{ACKNOWLEDGMENTS}

This paper benefited from helpful discussions with Jack Murata, George Claypool, Kerry Kelts, and Judy McKenzie. Joris Gieskes and George Claypool reviewed the manuscript and offered constructive suggestions. We thank Joe LeClaire for technical assistance in the analyses of total organic carbon, Tom Hilliard for preparation of illustrations, Vic Sotelo and Kevin Reid for photography help, and Lola Boyce for typing the manuscript. We gratefully acknowledge financial support for this investigation from Chevron Oil Production Research Laboratory, Geologic Research Division at Scripps Institution of Oceanography, and from the National Science Foundation under the auspices of the Deep Sea Drilling Project.

\section{REFERENCES}

Badiozamani, K., 1973. The Dorag dolomitization model-application to Middle Ordovician of Wisconsin. J. Sediment. Petrol., 43: 965-984.

Bottinga, Y., 1968. Calculation of fractionation factors for carbon and oxygen exchange in the system calcite-carbon dioxide-water. J. Phys. Chem., 72:800-808.

1969. Calculated fractionation factors for carbon and hydrogen isotope exchange in the system calcite- $\mathrm{CO}_{2}$-graphite-methane-hydrogen and water vapor. Geochim. Cosmochim. Acta, 33: 49-64.

Claypool, G. E., 1974. Anoxic diagenesis and bacterial methane production in deep sea sediments (Ph.D. thesis). University of California, Los Angeles.

Claypool, G. E., and Kaplan, I. R., 1974. The origin and distribution of methane in marine sediments. In Kaplan, I. R. (Ed.), Natural Gases in Marine Sediments: Mar. Sci., 3:99-139.

Claypool, G. E., Presley, B. J., and Kaplan, I. R., 1973. Gas analyses of sediment samples from Legs 10,11, 13, 14, 15, 18, and 19. In Creager, J. S., Scholl, D. W., et al., Init. Repts. DSDP, 19: Washington (U.S. Govt. Printing Office), 879-884.

Cooper, J. E., and Bray, E. E., 1963. A postulated role of fatty acids in petroleum formation. Geochim. Cosmochim. Acta, 27:11131127.

Craig, H., 1957. Isotopic standards for carbon and oxygen and correction factors for mass spectrometric analysis of carbon dioxide. Geochim. Cosmochim. Acta, 12:133-149.

Curtis, C. D., 1978. Possible links between sandstone diagenesis and depth-related geochemical reactions occurring in enclosing mudstones. J. Geol. Soc. London, 135:107-117.

Deffeyes, K. S., Lucia, F. J., and Weyl, P. K., 1964. Dolomitization; observations on the island of Bonaire, Netherlands, Antilles. Science, 143:678-679.

DeGiovani, W. F., Salati, E., Marini, O. J., et al., 1974. Unusual isotopic composition of carbonates from the Irati Formation, Brazil. Geol. Soc. Am. Bull., 85:41-44.

Deuser, W. G., 1970. Extreme ${ }^{13} \mathrm{C} / 12 \mathrm{C}$ variations in Quaternary dolomites from the continental shelf. Earth Planet. Sci. Lett., 8:118124.

Dunham, J. B., and Olson, E. R., 1979. Shallow subsurface dolomitization of subtidally deposited carbonate sediment in Hanson Creek Formation (Ordovician-Silurian), central Nevada-Evidence for groundwater mixing. Am. Assoc. Pet. Geol. Bull., 63: 442. (Abstract)

Eisma, E., and Jung, J. W., 1969. Fundamental aspects of the generation of petroleum. In Eglinton, G., and Murphy, M. T. J. (Eds.), Organic Geochemistry: New York (Springer-Verlag), pp. 676-698.
Folk, R. L., and Land, L. S., 1975. Mg/Ca ratio and salinity: two controls over crystallization of dolomite. Am. Assoc. Pet. Geol. Bull., 59:60-68.

Friedman, I., and Murata, K. J., 1979. Origin of dolomite in Miocene Monterey Shale and related formations in the Temblor Range, California. Geochim. Cosmochim. Acta, 43:1357-1365.

Friedman, I., and O'Neil, J. R., 1977. Compilation of stable isotope fractionation factors of geochemical interest. U.S. Geol. Surv. Prof. Paper 440-KK.

Fritz, P., and Smith, D. C. W., 1970. The isotope composition of secondary dolomites. Geochim. Cosmochim. Acta, 34:1161-1173.

Gieskes, J. M., 1975. Chemistry of interstitial waters of marine sediments. Ann. Rev. Earth Planet. Sci., 3:433-453.

Goldsmith, J. R., and Graf, D. L., 1958. Relation between lattice constants and composition of the Ca-Mg carbonates. Am. Mineral., 43:84-101.

Grechin, V. I., 1976. Miocene deposits of west Kamchatka (sedimentation and catagenesis). Trans. Acad. Sci. USSR, 282:1-137.

Hathaway, J. C., and Degens, E. T., 1969. Methane-derived marine carbonates of Pleistocene age. Science, 165:690-692.

Hein, J. R., O'Neil, J. R., and Jones, M. G., 1979. Origin of authigenic carbonates in sediments from the deep Bering Sea. Sedimentology, 26:681-705.

Irwin, H., Curtis, C. D., and Coleman, M., 1977. Isotopic evidence for source of diagenetic carbonates formed during burial of organic-rich sediments. Nature, 269:209-213.

Keith, M. L., and Weber, J. N., 1964. Carbon and oxygen isotopic composition of selected limestones and fossils. Geochim. Cosmochim. Acta, 28:1787-1816.

Kelts, K. R., and McKenzie, J. A., 1980. Formation of deep-sea dolomite in anoxic diatomaceous oozes. Twenty-sixth Internatl. Geol. Congr., Paris, France. (Abstract)

Kinsman, D. J. J., 1965. Gypsum and anhydrite of Recent age, Trucial coast, Persian Gulf. In Rau, J. L. (Ed.), Second Symposium on Salt: North. Ohio Geol. Soc., Cleveland, Ohio, 1:302-326.

Kitano, Y., and Kanamori, N., 1966. Synthesis of magnesian calcite at low temperatures and pressures. Geochim. J., 1:1-10.

Lawrence, J. R., Gieskes, J., and Broecker, W. S., 1975. Oxygen isotope and cation composition of DSDP pore waters and the alternation of Layer II basalts. Earth Planet. Sci. Lett., 27:1-10.

McCrea, J. M., 1950. On the isotopic chemistry of carbonates and a paleotemperature scale. J. Chem. Phys., 18:849-857.

McKenzie, J. A., Jenkyns, H. C., and Bennet, G. G. 1980. Stable isotope study of the cyclic diatomite-claystones from the Tripoli Formation, Sicily: a prelude to the Messinian salinity crisis. Paleogeogr. Palaeochim. Palaeoecol., 29:125-141.

Matthews, A., and Katz, A., 1977. Oxygen isotope fractionation during dolomitization of calcium carbonate. Geochim. Cosmochim. Acta, 41:1431-1438.

Milliman, J. D., 1974. Marine Carbonates: Heidelberg (Springer-Verlag), pp. 311-313.

Moore, G. W., and Gieskes, J. M., 1980. Interaction between sediment and interstitial water near the Japan Trench, DSDP Leg 57. In Scientific Party, Init. Repts. DSDP, 56, 57, Pt. 2: Washington (U.S. Govt. Printing Office), 1269-1276.

Murata, K. J., and Erd, R. C., 1964. Composition of sediments from the experimental Mohole project (Guadalupe site). J. Sediment. Petrol., 34:633-655.

Murata, K. J., Friedman, I., and Madsen, B. M., 1969. Isotopic composition of diagenetic carbonates in marine Miocene formations of California and Oregon. U.S. Geol. Surv. Prof. Paper 614-B.

Nissenbaum, A., Presley, B. J., and Kaplan, I. R., 1972. Early diagenesis in a reducing fjord, Saanich Inlet, British Columbia. I. Chemical and isotopic changes in major components of interstitial water. Geochim. Cosmochim. Acta, 36:1007-1027.

Northrup, D. A., and Clayton, R. N., 1966. Oxygen-isotope fractionations in systems containing dolomite. J. Geol., 74:174-196.

O’Neil, J. R., Clayton, R. N., and Mayeda, T. K., 1969. Oxygen isotopic fractionation in divalent metal carbonates. J. Chem. Phys., $51: 5547-5558$.

Raiswell, R., 1976. The microbiological formation of carbonate concretions in the Upper Lias of NE England. Chem. Geol., 18:227244. 
Rosenberg, P. E., Burt, D. M., and Holland, H. D., 1967. Calcitedolomite-magnesite stability relations-the effect of ionic strength. Geochim. Cosmochim. Acta, 31:391-396.

Rosenfeld, W. D., and Silverman, S. R., 1959. Carbon isotope fractionation in bacterial production of methane. Science, 130:16581659.

Russell, K. L., Deffeyes, K. S., Fowler, G. A., et al., 1967. Marine dolomite of unusual isotopic composition. Science, 155:189-191.

Sass, E., and Kolodny, Y., 1972. Stable isotopes, chemistry and petrology of carbonate concretions (Mishash Formation, Israel). Chem. Geol., 10:261-286.

Sawamura, K., and Uemura, F., 1973. Notes on diatomaceous carbonate nodules in the Neogene Tertiary system of Ajigasawa area, Aomori Prefecture. Geol. Surv. Jpn. Bull., 24:185-192.

Sayles, F. L., and Manheim, F. T., 1975. Interstitial solutions and diagenesis of deeply buried marine sediments: results from the Deep Sea Drilling Project. Geochim. Cosmochim. Acta, 39:103-127.

Sharma, T., and Clayton, R. N., 1965. Measurement of $\mathrm{O}^{18} / \mathrm{O}^{16} \mathrm{ra}-$ tios of total oxygen of carbonates. Geochim. Cosmochim. Acta, 29:1347-1353.

Sheppard, S. M. F., and Schwarcz, H. P., 1970. Fractionation of carbon and oxygen isotopes and magnesium between metamorphic calcite and dolomite. Contrib. Mineral. Petrol., 26:161-198.

Shinn, E. A., Ginsburg, R. N., and Lloyd, R. M., 1965. Recent supratidal dolomite from Andros Island, Bahamas. In Pray, C. C., and
Murray, R. C. (Eds.), Dolomitization and Limestone Diagenesis: Soc. Econ. Paleont. Mineral. Spec. Publ. 13:112-123.

Siever, R., Beck, K. C., and Berner, R. A., 1965. Composition of interstitial waters of modern sediments. J. Geol., 73:39-73.

Spotts, J. H., and Silverman, S. R., 1966. Organic dolomite from Point Fermin, California. Am. Mineral., 51:1144-1155.

Supko, P. R., Stoffers, P., and Coplen, T. B., 1974. Petrography and geochemistry of Red Sea dolomite. In Whitmarsh, R. B., Weser, O. E., Ross, D. A., et al., Init. Repts. DSDP, 23: Washington (U.S. Govt. Printing Office), 871-878.

Tarutani, R., Clayton, R. N., and Mayeda, T. K., 1969. The effects on polymorphism and magnesium substitution on oxygen isotope fractionation between calcium carbonate and water. Geochim. Cosmochim. Acta, 33:987-996.

Thompson, G., Bowen, V. T., Melson, W. G., et al., 1968. Lithified carbonates from the deep-sea of the equatorial Atlantic. J. Sediment. Petrol., 38:1305-1312.

Usdowski, H., 1968. The formation of dolomite in sediments. In Müller, G., and Friedman, G. M. (Eds.), Recent Developments in Carbonate Sedimentology in Central Europe: New York (SpringerVerlag), pp. 21-32.

Watanabe, M., 1970. Carbonate concretions in the Neogene Tertiary system, northeast Japan. Sci. Repts. Tohoku Univ., Ser. 3, 11:69112. 